\title{
Clinical Utility of Liquid Biopsy-Based Actionable Mutations Detected via ddPCR
}

\author{
Irina Palacín-Aliana ${ }^{1,2,3}$, Noemí García-Romero ${ }^{4,5}$ (D) Adrià Asensi-Puig ${ }^{1}$ (D) Josefa Carrión-Navarro ${ }^{4,5}$ (D), \\ Víctor González-Rumayor ${ }^{1}$ and Ángel Ayuso-Sacido $4,5,6, *$
}

1 Atrys Health, 08025 Barcelona, Spain; ipalacin@atryshealth.com (I.P.-A.); aasensi@atryshealth.com (A.A.-P.); vgrumayor@atryshealth.com (V.G.-R.)

2 Fundación de Investigación HM Hospitales, HM Hospitales, 28015 Madrid, Spain

3 Faculty of Science, Universidad de Alcalá, 28801 Madrid, Spain

4 Faculty of Experimental Sciences, Universidad Francisco de Vitoria, 28223 Madrid, Spain; noemi.garcia@ufv.es (N.G.-R.); pepa.carrion@ufv.es (J.C.-N.)

5 Brain Tumor Laboratory, Fundación Vithas, Grupo Hospitales Vithas, 28043 Madrid, Spain

6 Faculty of Medicine, Universidad Francisco de Vitoria, 28223 Madrid, Spain

* Correspondence: ayusosa@vithas.es; Tel.: +34-686-966-904

check for

updates

Citation: Palacín-Aliana, I.; García-Romero, N.; Asensi-Puig, A.; Carrión-Navarro, J.; GonzálezRumayor, V.; Ayuso-Sacido, Á. Clinical Utility of Liquid Biopsy-Based Actionable Mutations Detected via ddPCR. Biomedicines 2021, 9, 906. https://doi.org/ 10.3390/biomedicines 9080906

Academic Editor: Stefano Indraccolo

Received: 2 July 2021

Accepted: 23 July 2021

Published: 28 July 2021

Publisher's Note: MDPI stays neutral with regard to jurisdictional claims in published maps and institutional affiliations.

Copyright: (c) 2021 by the authors. Licensee MDPI, Basel, Switzerland. This article is an open access article distributed under the terms and conditions of the Creative Commons Attribution (CC BY) license (https:// creativecommons.org/licenses/by/ $4.0 /)$.

\begin{abstract}
Cancer is one of the leading causes of death worldwide and remains a major public health challenge. The introduction of more sensitive and powerful technologies has permitted the appearance of new tumor-specific molecular aberrations with a significant cancer management improvement. Therefore, molecular pathology profiling has become fundamental not only to guide tumor diagnosis and prognosis but also to assist with therapeutic decisions in daily practice. Although tumor biopsies continue to be mandatory in cancer diagnosis and classification, several studies have demonstrated that liquid biopsies could be used as a potential tool for the detection of cancerspecific biomarkers. One of the main advantages is that circulating free DNA (cfDNA) provides information about intra-tumoral heterogeneity, reflecting dynamic changes in tumor burden. This minimally invasive tool has become an accurate and reliable instrument for monitoring cancer genetics. However, implementing liquid biopsies across the clinical practice is still ongoing. The main challenge is to detect genomic alterations at low allele fractions. Droplet digital PCR (ddPCR) is a powerful approach that can overcome this issue due to its high sensitivity and specificity. Here we explore the real-world clinical utility of the liquid biopsy ddPCR assays in the most diagnosed cancer subtypes.
\end{abstract}

Keywords: liquid biopsy; ddPCR; cancer biomarkers; lung cancer; breast cancer; colorectal cancer; pancreatic cancer

\section{Introduction \\ 1.1. Background}

Despite many advances in the field, cancer remains one of the primary causes of death worldwide. In fact, estimations point to a total of 19.3 million new cases and almost 10 million deaths per year with no distinction between developed and undeveloped countries [1]. The most diagnosed cancer type worldwide is breast cancer followed by prostate cancer. On the other hand, lung cancer shows the highest mortality with an estimated 1,796,144 deaths worldwide in 2020 [2]. According to these statistics, it is not surprising that cancer has become the mainstay of research all over the world. In the last few years, many efforts in this field have been made, majorly in the diagnosis and prognosis of the different types of cancer, to assist clinicians to make more effective treatment selections through novel technologies. Nowadays, tumor tissue is the main source of information for diagnosis, stratification, prognosis, and treatment decision, discriminating between cancer or non-cancer lesions and providing significant information of different clinically relevant biomarkers [3-5]. 
Although tissue biopsies are crucial in the current evaluation and classification of cancer types, they present many limitations. Some of these relate to the highly invasive techniques required to obtain the biopsies and the risk to the patient associated with these procedures, as some tumors are hardly accessible due to their anatomical location and/or their infiltrative nature [5]. Also, tissue biopsies fail to represent the intra-tumoral heterogeneity since only a small fraction of the tumor obtained will be evaluated by physicians. To overcome this issue, liquid biopsies are present as a new minimally invasive tool for intra-tumoral monitoring which represents more accurately the tumoral status. Samples are collected from different biofluids, mostly from blood (serum and plasma) but also from saliva, breast milk, cerebrospinal fluid, stool, semen, urine, etc. [6]. Several biomarkers represented in Figure 1 could be isolated from different sources such as circulating tumor cells (CTCs), extracellular vesicles (EVs), cell-free DNA (cfDNA), and micro-RNA (miRNA).

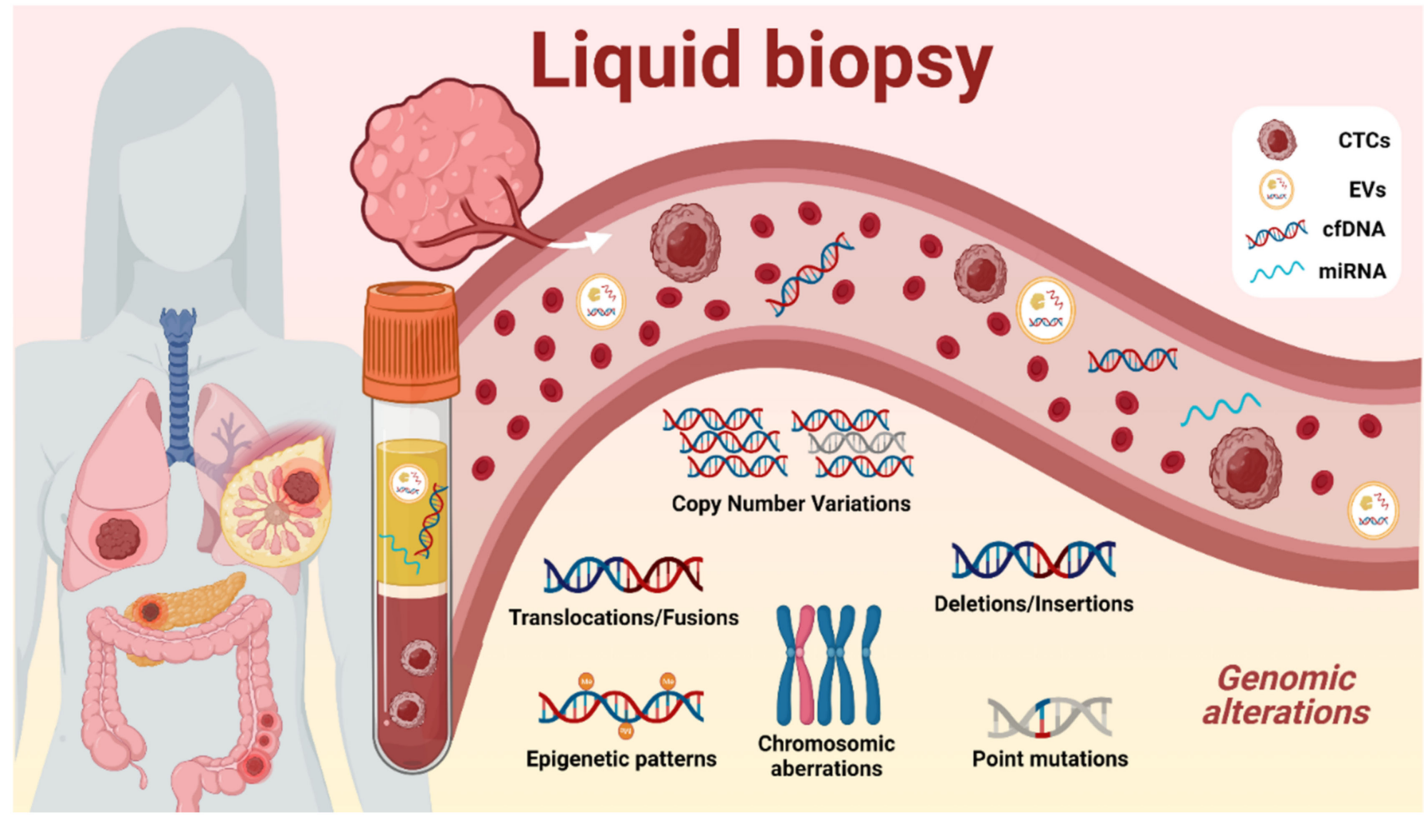

Figure 1. Schematic of the liquid biopsy composition. Liquid biopsy obtained from peripheral blood is composed of different tumoral components such as circulating tumor cells (CTCs), circulating cell-free DNA (cfDNA), extracellular vesicles (EVs), and micro-RNA (miRNA). These elements can be isolated for the identification of various tumor-specific genomic aberrations including point mutations, copy number variations, structural rearrangements, or epigenetic patterns.

The circulating DNA found in all biofluids is referred to as cfDNA, which includes tumor-derived fraction called circulating tumor DNA (ctDNA) [7]. Nevertheless, cfDNA has been proven to be a powerful tool since all tumor cells, indistinctly of their phenotype, secrete DNA into the biofluids, providing information of the whole tumor, and revealing a snapshot of the intra-tumoral heterogeneity state at the moment of sample collection [8]. The mostly minimal-invasive nature of liquid biopsies allows clinicians to be informed about the molecular evolution of the tumor genetics, permitting disease monitoring, and avoiding the classical biopsies that could endanger the patient. The amount and length of ctDNA has been investigated due to its potential capacity for early detection and prognosis of some tumors. Also, in the current state of the art, ctDNA techniques are capable of detecting the genomic aberrations represented in Figure 1, such as copy number variations (CNVs), methylation changes in DNA promoters, and single-nucleotide variations (SNVs) in a biofluidic sample [9], giving remarkable information about treatment response, tumoral staging, prognosis, minimal residual disease, and actionable mutations, enhancing more precise clinical decisions. 


\subsection{Droplet Digital PCR (ddPCR)}

Nowadays, there are many technologies that allow for the detection of the ctDNA fraction [10]. Although the traditional PCR-based assays are the cheapest ones, they have limited sensitivity and specificity [11]. Due to the novel mutational status information provided in one single assay by the next-generation sequencing (NGS) technique, their sensitivity and specificity have increased to $0.1 \%[11,12]$. On the downside, NGS is expensive, highly time-consuming, and requires well-experienced bioinformaticians to discriminate between actionable tumoral mutations and normal tissue background [13]. In this context, droplet digital PCR (ddPCR) has newly emerged as a powerful and cost-effective tool [14], capable of the detection and absolute quantification of point mutations up to $0.01 \%$ with no need for specific bioinformatic interpretation (Table 1) [15,16].

Table 1. Comprehensive comparison of liquid biopsy analysis techniques.

\begin{tabular}{|c|c|c|c|c|c|c|c|}
\hline Technique & Sensitivity & Specificity & LoD & Advantages & Limitations & Price & References \\
\hline $\begin{array}{l}\text { PCR-based } \\
\text { techniques } \\
\text { (qRT-PCR, } \\
\text { COLD-PCR) }\end{array}$ & $29-95.7 \%$ & $69.2-100 \%$ & $0.1 \%$ & $\begin{array}{l}\text { Rapid. } \\
\text { No bioinformatic analysis } \\
\text { required. }\end{array}$ & $\begin{array}{l}\text { Screening of a few } \\
\text { known mutations } \\
\text { at a time. }\end{array}$ & Low & {$[6,11,17,18]$} \\
\hline $\begin{array}{c}\text { Drop-digital } \\
\text { PCR }\end{array}$ & $66.7-90 \%$ & $100 \%$ & $0.01 \%$ & $\begin{array}{c}\text { Rapid. } \\
\text { High sensitivity. } \\
\text { Applicable for the detection of } \\
\text { specific point mutations, } \\
\text { copy-number variations, short } \\
\text { indels, and gene fusions. } \\
\text { No bioinformatic analysis required. } \\
\text { Cost-effective. }\end{array}$ & $\begin{array}{l}\text { Screening of a few } \\
\text { known mutations } \\
\text { at a time. }\end{array}$ & Medium & {$[6,11,15,19]$} \\
\hline $\begin{array}{l}\text { NGS-based } \\
\text { approaches }\end{array}$ & $50.9-100 \%$ & $70-100 \%$ & $0.1 \%$ & $\begin{array}{l}\text { Molecular alteration knowledge } \\
\text { not required } \\
\text { Analysis of several alterations in } \\
\text { several genes at the same time. }\end{array}$ & $\begin{array}{l}\text { Expensive. } \\
\text { Limited } \\
\text { sensitivity. } \\
\text { Highly } \\
\text { time-consuming. } \\
\text { Experienced } \\
\text { bioinformaticians }\end{array}$ & High & {$[6,11,15,20,21]$} \\
\hline
\end{tabular}

LoD = limit of detection. COLD-PCR, co-amplification at lower denaturation temperature PCR. NGS = next-generation sequencing.

As shown in Figure 2, ddPCR divides the nucleic acids into thousands of individual end-point PCR reactions permitting their single analysis via oil sphere microfluidics. In oncology, ddPCR is further being used not only for point mutations detection and absolute quantification but is also currently employed for rare mutation detection, CNVs, DNA methylation, and gene rearrangements screening in different sources of clinical samples $[14,22]$.

The near future of cancer diagnosis, prognosis, and treatment is expected to explore liquid biopsy biomarkers as an additional test to guide clinicians in every step of disease management. In this sense, an increasing number of cancer-derived biomarkers are being identified. In this review, we unify and classify different acknowledged and potentially actionable mutations that are relevant in lung, breast, colorectal, and pancreatic tumors, for further detection by ddPCR in clinical laboratories, in order to ease the way for clinicians in every step of disease management, striving to advance efforts in cancer diagnosis, prognosis, and treatment. To the best of our knowledge, this is the first report that presents a compendium of all the ongoing liquid biopsy-ddPCR clinical trials. 


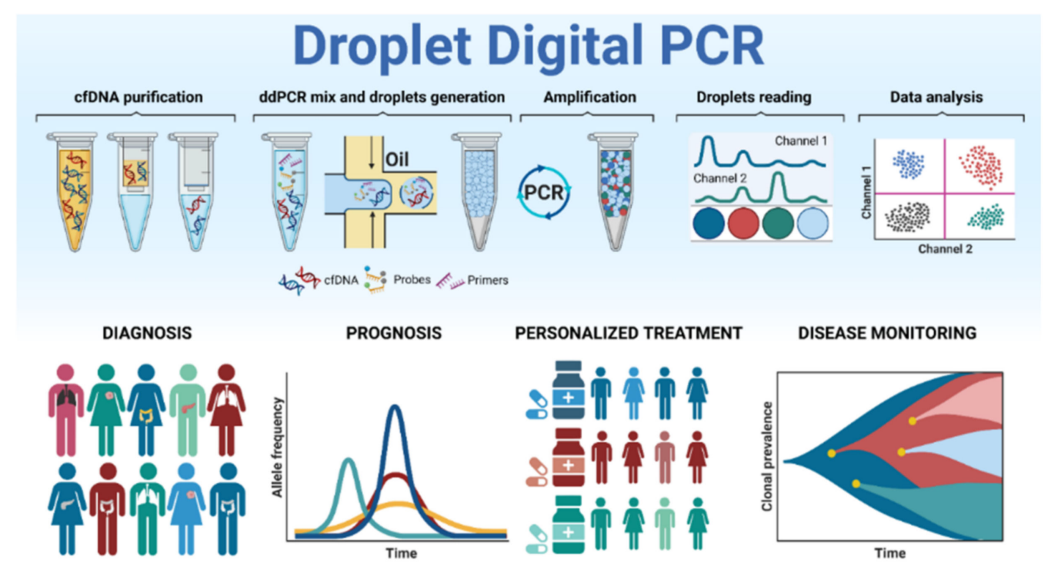

Figure 2. Summary of the ddPCR alterations screening process. The purified cfDNA is divided into thousands of oil droplets together with specific primers and probes. The ddPCR currently has several applications such as cancer diagnosis, prognosis, personalized treatment administration, and disease monitoring.

\section{Lung Cancer}

Despite all the advances made in the past years, lung cancer remains the leading cause of neoplastic death worldwide [1]. The gold standard for non-small cell lung cancer (NSCLC) genotyping is the analysis of different driver genes such as EGFR, BRAF, HER2, $K R A S$, and MET, as well as rearrangements in ALK, ROS1, RET, and NTRK1/2/3 [23,24], typically analyzed by PCR-based assays, immunohistochemistry (IHC), and fluorescent in situ hybridization assays (FISH) [25]. The introduction of genetic studies has significantly improved targeted therapies and subsequently patient's progression-free survival (PFS) and overall survival (OS). Some of the successful treatments involve immunotherapies, such as the inhibition of the PD-1/PD-L1 axis [26]. ddPCR was also used for these immune targeted markers in solid [27] and liquid biopsies [28].

Routinely, the testing for molecular tumor alterations is performed on resected tissue biopsies. However, in some situations, when there is insufficient material for molecular analysis or the patient is unfit for invasive tissue sampling, the analysis of cfDNA has already been introduced [29].

\subsection{EGFR}

The epidermal growth factor receptor, known as EGFR, is one of the most characterized genes in lung cancer and appears in around 10-35\% of NSCLC patients [30]. EGFR mutations (exon 21 L858R and L861Q or EGFR exon 19 deletions) represent $85 \%$ of EGFR mutations [24,30,31], which confer sensitivity to EGFR tyrosine kinase inhibitors (TKIs) [23], and could be detected by multiplexed ddPCR assays with a sensitivity of at least $0.20 \%$ [32]. The most common TKIs used in clinical practice are erlotinib, gefitinib, and neratinib [33]. Guidelines recommend EGFR mutation genotyping to guide personal therapy by identifying NSCLC patients that may benefit EGFR-TKIs [34]. Unfortunately, after 8-14 months of first-line TKIs treatment, most of the patients acquired therapy resistance resulting in disease progression or relapse. This acquired resistance is caused mainly by the appearance of the T790M mutation in $60 \%$ of the NSCLC patients [30,31]. Therefore, its detection by ddPCR has been implemented in several hospitals and a wide set of studies highlights its importance. In a large cohort of 343 NSCLC patients, EGFR T790M was detected in $24 \%$ of patients by ddPCR [35]. These data were further corroborated in a smaller cohort of patients in progression, in which they detected $52 \%$ of positive samples with a cfDNA frequency of $0.5 \%$ [36].

For the treatment of those patients who acquired first-generation resistance, a thirdgeneration TKI therapy, osimertinib, has been developed. Different studies quantified the mutation allele frequency (MAF) of the T790M mutation before and during the course of osimertinib treatment $[34,37]$. A retrospective study observed how patients with partial 
response or stable disease to second-line therapy with osimertinib had higher T790M mutant frequency in plasma cfDNA than those with progressive disease. Although higher T790M MAF levels were associated with longer PFS and OS [38], Li et al. didn't report differences in response rate or PFS and OS [39]. Additional studies are needed for the standardization of the MAF quantification cutoff value and to assess whether the quantitative measurements of plasma cfDNA T790M mutation could be used to predict TKIs therapy response.

Inevitably, novel acquired EGFR mutations conferring third-generation TKI osimertinib resistance have been observed. Approximately $20-40 \%$ of these cases are caused by the C797S mutation, which avoids drug covalent binding [40]. Via ddPCR, EGFR T790M and C797S mutations have been longitudinally assessed in plasma cfDNA during and after treatment [41]. A recent report showed three molecular patterns based on the presence/absence of T790M, C797S, and Ex19Del mutations, which could help in clinical decisions [40]. Serial evaluation of different EGFR mutations in plasma cfDNA during osimertinib treatment may be useful as a prognostic factor for disease progression. More importantly, those patients with T790M mutation clearance and detectable levels of C797S resistance mutation together with a sensitizing EGFR mutation may benefit from first-generation TKIs re-treatment $[42,43]$.

Apart from the most scrutinized mutations in EGFR, some researchers are focused on the development of ddPCR assays for less common mutations, such as G719S and L851Q, in advanced NSCLC patients [44].

The detection of EGFR mutations has been explored in other liquid biopsies as the bronchial washing fluid (BWF) $[45,46]$, the fine-needle aspiration (FNA) supernatants, sputum, and urine [47-49]. Lastly, for lung cancer patients that develop metastases to the central nervous system (CNS), detection of EGFR mutations in the cerebrospinal fluid (CSF) has been proven to be more efficient than plasma to evaluate PFS [50].

\subsection{KRAS}

$K R A S$ is an oncogenic driver gene that appears to be mutated in $25-30 \%$ of NSCLC patients [51]. Mutations in codons 12 and 13 of this gene are the most frequent alterations and stand as the principal cause of the development and progression of several cancer types [52]. Despite all clinical advances in personalized therapies and their proven impact on patient's clinical outcome, there is only one effective drug (sotorasib) [53] approved by the Food and Drug Administration (FDA) for KRAS G12C NSCLC patients [54,55].

It has been suggested that KRAS mutations decrease EGFR-TKIs sensitivity through the MAPK/ERK pathway activation in NSCLC patients $[53,56]$. Moreover, the presence of $K R A S$ mutations is also related to high PD-L1 levels, suggesting that those patients could be good responders to immune checkpoint inhibitors [57]. In contrast, KRAS mutations appear to decrease the anti-angiogenic bevacizumab effects [58].

The design of ddPCR multiplex assays to detect the most frequent G12/G13 KRAS mutations has allowed for rapid and accurate genotyping of plasma cfDNA with a LOD of at least $0.2 \%[51,52,59,60]$. As a result of these assays, an association between $K R A S$ mutated concentration and disease stage has been observed. Patients with advanced lung cancer stages present greater amounts of detectable KRAS mutations in plasma cfDNA samples, being $8 \%$ in stage I, 30\% in stage II, $71 \%$ in stage III, and $73 \%$ in stage IV [51]. Furthermore, it has been observed that patients with stable disease presented lower $K R A S$ mutations levels than patients who had progressed [52]. Also, several studies have associated plasma ctDNA KRAS mutations with shorter PFS and OS [51,52,59,60], and chemotherapy treatment efficacy has been longitudinally monitored, showing a connection between ctDNA KRAS concentration changes and therapy response [51,61,62].

Despite being a limited druggable target mutation, the analysis of ctDNA KRAS mutations could be used as a prognostic and predictive tool and may guide alternative therapy approaches such as chemotherapy or immunotherapy. 


\subsection{ALK}

The tyrosine kinase receptor $A L K$ is found rearranged, mostly with Echinoderm Microtubule-Associated Protein-like 4 (EMLA4), in approximately $5 \%$ of NSCLC patients, causing inappropriate signaling which induces an activated state in cancer cells [63]. The gold standard, with a LOD of $15 \%$, is its direct visualization by FISH or IHC [64]. Conversely, NGS has been recently recommended for the identification of different NSCLC rearrangements, including $A L K$ [65]. As a more sensitive technique, a ddPCR assay has been designed to detect $A L K$-EMLA4 gene translocations with a LOD of $0.25 \%$ in formalinfixed paraffin-embedded (FFPE) samples [64].

Patients presenting ALK-EML4 rearrangements appear to be sensitive to the ALK-TKIs crizotinib, ceritinib, alectinib, brigatinib, and lorlatinib [29,66,67]. Approximately $20 \%$ of patients with $A L K$ rearrangements treated with first-generation ALK-TKI crizotinib develop resistance due to mutations in the kinase domain [68]. Although the most common and relevant $A L K$ resistance mutations are the $\mathrm{G} 1202 \mathrm{R}$ and $\mathrm{F} 1174 \mathrm{C} / \mathrm{L}$, there are more than 10 mutations described which confer resistance to first-generation ALK-TKIs, such as L1196M, G1269A, C1156Y, 1151Tins, L1152R, S1206Y, I1171T, D1203N, and V1180L (Table 2) $[67,69]$. For those patients who develop resistance, second-generation ALKTKIs ceritinib, alectinib, and brigatinib have been developed [68]. Unfortunately, G1202R mutation confers resistance to second-generation ALK-TKIs in some of the patients [70], which could be treated with lorlatinib (a third-generation ALK-TKI inhibitor). Three ddPCR multiplexed assays are available to specifically detect the 10 previously detailed ALK mutations. In a small cohort of $7 A L K$-positive NSCLC, the monitoring of the different $A L K$ resistance mutations status during the course of the disease was successfully performed [71] but further and wider studies are required to assess the ddPCR clinical utility to detect $A L K$ secondary mutations and their implication in patients PFS and OS. In any case, these assays offer a fast and sensitive technique for the monitoring of newly discovered resistance mutations by minimally invasive cfDNA liquid biopsies.

Table 2. The most relevant molecular alterations detected via ctDNA ddPCR assays and their clinical significance in NSCLC.

\begin{tabular}{|c|c|c|c|c|}
\hline Disease & Oncogene & Alteration & Clinical Significance & References \\
\hline \multirow{6}{*}{ NSCLC } & \multirow{3}{*}{ EGFR } & $\begin{array}{l}\text { Exon } 19 \text { del } \\
\text { L858R } \\
\text { L861Q }\end{array}$ & Sensitivity to first-generation EGFR-TKIs & {$[23,24,30-32]$} \\
\hline & & T790M & $\begin{array}{l}\text { Resistance to first- and second-generation } \\
\text { EGFR-TKIs and } \\
\text { sensitivity to third-generation EGFR-TKIs }\end{array}$ & {$[30,31,34-39]$} \\
\hline & & C797S & Resistance to third-generation EGFR-TKIs & [40-43] \\
\hline & \multirow{2}{*}{ KRAS } & G12/G13 & Poor prognosis and decreased EGFR-TKIs sensitivity & {$[51-53,56-60,62]$} \\
\hline & & G12C & Sensitivity to sotorasib & {$[54,55]$} \\
\hline & $A L K$ & $\begin{array}{l}\text { Mutations in the } \\
\text { tyrosine kinase domain }\end{array}$ & $\begin{array}{l}\text { G1202R, F1174C/L L1196M, G1269A, C1156Y, } \\
\text { 1151Tins, L1152R, S1206Y, I1171T, D1203N, and } \\
\text { V1180L mutations may confer resistance or } \\
\text { sensitivity to the different ALK-TKIs } \\
\text { therapies available }\end{array}$ & [67-71] \\
\hline
\end{tabular}

\section{Breast Cancer}

Breast cancer $(\mathrm{BC})$ has recently surpassed lung cancer as the most lethal and diagnosed neoplasm in women [1]. Routinely for clinical practice, BC is classified into five subtypes based on histological and molecular characteristics [72]. Tumors expressing estrogen receptor (ER) and/or progesterone receptor (PR) are considered hormone receptor (HR)positive $\mathrm{BC}$ and those expressing the human epidermal growth factor receptor 2 (HER2 or ERBB2) are diagnosed as HER2-positive BC. Samples with no ER, PR, nor HER2 expression, 
are classified as triple-negative breast cancer (TNBC) [72]. These markers are used to guide personalized treatment administration and to predict responses to endocrine and immune therapy.

Novel agents, which effectiveness depends on specific genomic aberrations, are being developed. The most common targets are PIK3CA, HER2, androgen receptor $(A R), A K T 1$, ESR1, and PD-L1 [73]. The evaluation of the tumor genomic alterations in plasma cfDNA has been largely evaluated especially in metastatic $\mathrm{BC}(\mathrm{mBC})$ patients due to the high levels of ctDNA released into the bloodstream. The appearance of more sensitive technology than Sanger sequencing such as ddPCR has confirmed the presence of ctDNA before and after surgery in early-stage BC patients [74], in which it can predict tumor recurrence even 11 months earlier than traditional methods [75,76]. The assessment of cfDNA has great benefits for therapy guidance and a prognostic value in all BC disease stages.

\section{1. $B R C A$}

A $10 \%$ of BC cases are hereditary and associated with family clinical history [72]. The $B R C A$ family genes are the most frequently mutated in $B C$, whose aberrations increase the risk of developing $\mathrm{BC}$ up to 70\% [72]. Patients harboring $B R C A$ alterations may benefit of poly (ADP-ribose) polymerase (PARP) inhibitors increasing PFS, OS and their quality of life [72].

A wide spread of BRCA gene alterations have been described, such as point mutations, large genomic rearrangements or CNVs. Sanger sequencing and Multiplex ligationdependent probe amplification (MLPA) were thought to be the most reliable methods [77]. Despite excellent concordance rate between MLPA and dAPCR in the detection of BRCA1 genomic rearrangements [78], it is six times more expensive and requires at least one separate reaction for each gene exon. In this sense, a more cost-effective ddPCR based on an amplitude multiplex has been developed covering all coding and non-coding exons, together with two reference genes (RPP30 and $A L B)$ [79].

Even though ddPCR can be useful for genotyping BRCA genes in liquid biopsies, further optimization and standardization in larger cohorts is needed to clarify its clinical application and significance.

\subsection{PIK3CA}

Hormonal therapies have greatly improved ER-positive mBC patient outcomes. Unfortunately, PIK3CA exon 9 E545K and E542K, and PIK3CA exon 20 H1047R, and H1047L mutations are frequently associated with resistance to hormonal therapies, such as fulvestrant $[72,80]$. For this reason, the identification of those biomarkers in plasma ctDNA could be used to predict BC treatment. In fact, a relationship has been shown between these mutations and a good response to anti-PI3K and anti-CDK4/ 6 targeted therapies together with fulvestrant in HR-positive HER2-negative advanced BC [81,82].

ddPCR was used to analyze PIK3CA ctDNA mutations in the PALOMA-3 (NCT01942135), MIRHO (NCT01612871), and BOLERO-2 (NCT00863655) clinical trials. Although PALOMA3 and MIRHO trials did not report an association between PIK3CA baseline status and PFS, it has been shown that BC PIK3CA-mutated patients treated with a combination of palbociclib and fulvestrant improves PFS [80,82]. In contrast, the mutational analysis from patients enrolled in the BOLERO-2 trial receiving second-line treatment with everolimus, an mTOR1 inhibitor, showed that PIK3CA mutations had no effect on its effectiveness and that they are not a predictive determinant for everolimus benefit [83].

It has been widely proven that early identification of the mBC ctDNA PIK3CA mutation status, could allow future evaluation of disease response or progression and eventually, better treatment administration.

\subsection{ESR1}

Another interesting gene to point out is the ESR1 ligand-binding domain (LBD), which is mutated in $30-40 \%$ of ER-positive mBC patients [84,85]. Importantly, a significant 
number of $\mathrm{mBC}$ patients treated with first-line aromatase inhibitors (AIs) acquire ESR1 LBD mutations during the treatment developing endocrine treatment resistance $[84,86,87]$. Through ddPCR, several researchers have analyzed the ESR1 mutational status in peripheral blood [86,88,89]. The presence of ESR1 Y537S and D538G mutations in ER-positive $\mathrm{mBC}$ has been observed prior to treatment administration [90]. A significant increase in mutation prevalence was observed in patients who already received first-line AI therapy compared with those patients who only received adjuvant AI therapy [90]. Further analysis demonstrated the association of Y537S and D538G ESR1 mutations with worse OS.

The clinical significance of monitoring ESR1 LBD mutations Y537S, Y537N, Y537C, and D538G has been assessed in a cohort of sequential plasma samples from $\mathrm{mBC}$ and ER-positive primary BC treated with different endocrine therapies [91]. ddPCR data presented the ctDNA ESR1 mutation fluctuation as a consequence of treatment and showed that increasing amounts of ESR1 mutation post-therapy resulted in a poor response to treatment [91].

Various multiplexed assays have been developed to easily and simultaneously monitor different hotspot mutations in the ESR1 LBD gene. The decrease of ESR1 Y537S, Y537N, and D538G plasma detection in ER-positive BC women increase PFS and therapy effectiveness [84]. This impact has also been observed using another multiplex assay, in which eight different mutations; E380Q, L536H, L536R, Y537C, Y537N (T > A), Y537N (delinsTA), Y537S, and D538G were studied with high sensitivity and a LOD of $0.07-0.19 \%$ [92].

Even though ESR1 mutations have been principally detected in $\mathrm{mBC}$, the ddPCR implementation allows detection of $E S R 1$ mutations in approximately $2.5-7 \%$ of primary BC [93]. Furthermore, it has been observed that ESR1 mutations can be more frequently detected in cfDNA than in tissue biopsies [88].

\subsection{HER2}

HER2 is amplified in approximately $20-30 \%$ of invasive BC patients. HER2 overexpression causes tumor cell proliferation, aggressiveness, and subsequently, poor prognosis [72] Nowadays, the combination of monoclonal antibodies trastuzumab or pertuzumab with chemotherapy has improved the PFS and OS in patients with early-stage and metastatic BC (Table 3) [94]. Despite the benefit of this combined therapy, some patients do not respond to treatment administration, resulting in poor survival.

Table 3. Most relevant molecular alterations detected via ctDNA ddPCR assays and their clinical significance in BC.

\begin{tabular}{|c|c|c|c|c|}
\hline Disease & Oncogene & Alteration & Clinical Significance & References \\
\hline \multirow{4}{*}{$\begin{array}{l}\mathrm{BC} \text {, advanced } \mathrm{BC} \text {, } \\
\text { and } \mathrm{mBC}\end{array}$} & $B R C A 1 / B R C A 2$ & $\begin{array}{l}\text { Point mutations, large genomic } \\
\text { rearrangements or CNVs }\end{array}$ & Response to PARP inhibitors & {$[72,78,79]$} \\
\hline & PIK3CA & $\begin{array}{l}\text { E545K, E542K, H1047R } \\
\text { and H1047L }\end{array}$ & Hormonal therapies resistance & [80-83] \\
\hline & ESR1 & $\begin{array}{c}\text { E380Q, L536H, L536R, Y537C, } \\
\text { Y537N (T > A), Y537N (delinsTA), } \\
\text { Y537S and D538G }\end{array}$ & Endocrine treatment resistance & {$[84,86-92]$} \\
\hline & HER2 & $\mathrm{CNV}$ & $\begin{array}{c}\text { Response to } \\
\text { trastuzumab, pertuzumab, } \\
\text { lapatinib, or } \\
\text { trastuzumab emtansine }\end{array}$ & [95-97] \\
\hline
\end{tabular}

The gold standard approach to assess HER2 amplification in tissue samples is IHC or FISH [72]. Although little is known about the HER2 amplification detection in liquid biopsies, a ddPCR assay has been optimized to detect its CNVs in plasma [95]. To ensure proper detection, the gene EFTUD2 (elongation factor Tu GTP-binding domain 2) was used as a reference. The designed HER2:EFTUD2 ddPCR assay showed a high concordance of $90 \%$ with matched tumor biopsies [95], 100\% sensitivity, and 98\% specificity in a cohort 
of $76 \mathrm{BC}$ patients [96]. Even though the protocol has been principally developed for the detection of plasma-derived cfDNA it can be adapted for FFPE or fresh frozen tissue samples [97].

These minimally invasive tests that identify HER 2 amplification would be a clinical turnaround. Additionally, this approach could be modified for the evaluation of any amplified gene in cancer. Especially, it might be a beneficial approach for unusual acquisition events in response to therapy. Future prospective studies with larger cohorts should be conducted to evaluate these potential biomarkers and to optimize the ddPCR assays.

\section{5. ddPCR Assays for Multiplex Genes}

ddPCR multiplexed assays have been introduced as procedures to reduce the number of reactions and the sample volume employed. A prospective study developed eight optimized multiplexed ddPCR assays for 20 targetable hotspot mutations in the PIK3CA (E545K, H1047L, H1047R, and E542K), ESR1 (Y537C, Y537N, Y537S, V534E, S463P, L536Q, E380Q, D538G, and L536R), AKT1 (E17K), and HER2 (L869R, L755S, V777L, S310F, D769H, and L755_759del). Data were compared with NGS results, revealing an excellent concordance of $79.5 \%$. Since the NGS technique is not as sensitive as ddPCR, the major reason for the discordant cases were mutations detected by ddPCR and undetectable with NGS [73].

A similar multiplexed assay has been used for the evaluation of the possible effects of delayed plasma processing. For that, paired blood samples were processed immediately for $48-72 \mathrm{~h}$ after collection, in which the agreement in mutation screening was as high as $94.8 \%$ [98].

\subsection{Other}

$\mathrm{BC}$ cancer stem cells (BCSCs) are being investigated as a novel therapeutic approach to identify early genetic alterations in tumor evolution [99]. In a prospective study, plasma cfDNA from patients with early-stage and advanced $\mathrm{BC}$ were used to detect, through ddPCR, previously studied BCSC gene mutations [100]. BCSC ribosomal protein L39 (RPL39), A14V, and myeloid leukemia factor 2 (MLF2) R158W mutations were detected in $29 \%$ of cfDNA samples from early-stage BC patients and in $40 \%$ of $\mathrm{mBC}$. The presence of any of the mutations was associated with significantly worse OS and interestingly, the increasing BCSCs gene mutation detection in the patients' plasma cfDNA highly correlated with the disease stage.

\section{Colon and Rectal Cancers}

Colorectal Cancer (CRC) follows lung and breast cancers as the third neoplasm cause of death [1]. Due to the delayed start of symptoms, less than $40 \%$ of the patients are diagnosed with early-stage or localized disease. Consequently, the majority of patients are diagnosed with advanced localized disease and/or distant metastases, both with a high risk of recurrence after surgical resection [101].

CRC is known to be initiated by an accumulation of several mutations in a subset of crucial genes involved in the regulatory pathways. These genes, such as APC, KRAS, BRAF, PIK3CA, and SMAD4, are highly implicated in cellular replication, proliferation, and invasiveness [101]. Since CRC release elevated quantities of DNA into the bloodstream, several studies have described the potential use of plasma cfDNA in the diagnosis, management of patients, and as a tumor recurrence marker (Table 4) [102]. 
Table 4. The most relevant molecular alterations detected via ctDNA ddPCR assays and their clinical significance in CRC and PC.

\begin{tabular}{cccccc}
\hline Disease & Oncogene & Alteration & Clinical Significance & References \\
\cline { 2 - 6 } & KRAS & G12/G13 & $\begin{array}{c}\text { Non-responsiveness to anti-EGFR monoclonal } \\
\text { antibodies therapy such as panitumumab }\end{array}$ & {$[102-114]$} \\
Colorectal Cancer & BRAF & V600E & $\begin{array}{c}\text { Anti-EGFR monoclonal antibodies therapy such } \\
\text { as cetuximab and panitumumab are not } \\
\text { recommended unless given with a } B R A F \\
\text { inhibitor such as vemurafenib or MEK and } \\
\text { PI3K inhibitors }\end{array}$ & $\begin{array}{c}{[105,106,109,115-118]} \\
\text { Pancreatic cancer }\end{array}$ \\
\cline { 2 - 6 } & KRAS & G12/G13 & Associated with poor prognosis and OS & [120-129] \\
\hline
\end{tabular}

\subsection{KRAS and BRAF}

Over the last decade, most therapies have been designed to target aberrant signaling or activation of the MAPK pathway, such as the overexpression of EGFR found in $50-80 \%$ of patients $[113,117,130]$. Unfortunately, KRAS or BRAF mutations trigger nonresponsiveness to anti-EGFR monoclonal antibody therapies [115-117]. KRAS mutations G12/G13 are observed in about $35-45 \%$ of CRC patients $[111,117]$ and the first-line of treatment relies on a combination of chemotherapy of fluoropyrimidine with oxaliplatin or irinotecan [111]. BRAF shows lower mutation rates and appears in about $8-12 \%$ of metastatic CRC (mCRC), with V600E being the most common [118]. Although, the use of $B R A F$ inhibitors alone such as vemurafenib did not reach the expected effectiveness, the combination with anti-EGFR monoclonal antibodies, MEK, and/or PI3K inhibitors have shown promising outcomes [118].

Different PCR-based platforms (Bio-Rad ddPCR, BioCartis Idylla, Roche COBAS z480, and Sysmex BEAMing) have been tested for the detection of plasma ctDNA KRAS mutations. Among the four platforms, ddPCR and BEAMing resulted to be the most sensitive techniques. In addition, ddPCR and COBAS were the ones that allowed the analysis of a higher number of samples per reaction [103]. Another retrospective study used mCRC plasma ctDNA to compare COLD-PCR, a microarray-based approach, and ddPCR. As expected, ddPCR showed the highest concordance in the identification of ctDNA mutations previously genotyped on tissue samples [107]. Furthermore, ddPCR was demonstrated to be the faster protocol, the most cost-effective method with the higher sample throughput setup, and the most suitable and replicable technology to assess the tumor genotype using liquid biopsies [107,108].

The DECALIB study was one of the first prospective studies to use the ddPCR technique to evaluate and compare the early detection of $K R A S$ and $B R A F$ mutations present in plasma cfDNA and tissue [109]. Afterwards, many other studies have also evaluated the concordance between tissue and plasma KRAS mutations obtaining elevated specificity and sensitivity rates [102,110]. Even though many different manuscripts have observed better correlations between cfDNA concentrations and the tumor mutation burden in mCRC $[107,110,131]$, the cfDNA analysis could be also performed in patients at earlier cancer stages [102,110].

Longitudinal analysis of circulating $K R A S$ concentrations in $\mathrm{mCRC}$ has great prognostic value since it has the ability of outcome prediction and treatment monitoring. In a KRASpositive mCRC cohort from the prospective multicenter AIO KRK0207 trial (NCT00973609), ctDNA KRAS mutations were quantified via ddPCR before and 2-3 weeks after first-line chemotherapy initiation with fluoropyrimidine, oxaliplatin, and bevacizumab. Individuals with ctDNA KRAS mutations detected at baseline and in follow-up measurements presented worse OS and PFS. Remarkably, KRAS mutations identified at baseline in 15\% of the patients were not detectable at follow-up measurements after treatment initiation. 
Those patients with KRAS mutation clearance at follow-up had better disease control and most notably better OS and PFS [111]. The same results have been observed by Holm et al. in patients included in the AXOAXI trial (NCT01531595 and EudraCT 2011-003137-33), treated with bevacizumab in combination with altering capecitabine and oxaliplatin or irinotecan [132], or by Kelin-Scory et al. where KRAS mutations cleared precipitously independently of type and intensity of chemotherapy and regardless of bevacizumab anti-VEGF treatment [112]. KRAS mutations have been detected 10 months earlier than radiographic confirmation of disease progression [113]. More remarkably, these ctDNA $K R A S$ fluctuations and final disappearance open the possibility and potential treatment effectiveness of anti-EGFR therapies in those CRC patients [112,114].

Alternative sources of DNA such as EVs and fluids in the surrounding area of the tumoral tissue have been shown to provide information about disease evolution [104,133]. Fluids in the surrounding tumoral area such as the peritoneal fluid have been shown to be useful liquid biopsy sources of cfDNA [104]. In CRC patients with peritoneal metastases, a significantly higher amount of $K R A S$ or $B R A F$ ctDNA has been observed in peritoneal fluid than in plasma [105]. Since urine collection can be easily and repeatedly self-performed at any location with minimal effort, it has also been presented as an alternative source of cancer biomarkers for disease progression and drug response monitoring. In a proofof-concept study with a KRAS-positive mCRC cohort, KRAS or BRAF mutations were screened from urine and matched plasma samples. Even though the concordance achieved was low, they showed the feasibility of using urine samples for non-urogenital tract tumor mutation screening [106].

\subsection{Microsatellite Instability (MSI)}

The DNA mismatch repair deficiency (dMMR) causes the accumulation of a high number of DNA replication errors in DNA microsatellites. This phenome is termed as microsatellite instability (MSI) $[119,134]$. The frequency of dMMR/MSI-High (MSI-H) in CRC patients is $15 \%$ in early stages and $4-2 \%$ in mCRC [134]. Over the last few years, $\mathrm{dMMR} /$ High-MSI (MSI-H) testing has become key for all advanced CRC cancers since it is a predictive pan-tumor biomarker of immunotherapy treatment efficacy [135].

Minimally invasive detection of MSI-H from ctDNA is a promising diagnostic and treatment monitoring tool. A ddPCR assay has been developed to assess the microsatellite markers BAT-26, activin A receptor type 2A (ACVR2A), and defensin beta 105A/B (DEFB105A/B). The MSI-ddPCR assays were validated in tissue and blood samples achieving a sensitive detection of $<0.1 \mathrm{MAF}$ and a $100 \%$ of concordance with the most commonly used commercial kit, the pentaplex-PCR assay [119].

The new MSI-ddPCR assay promises to be a cost-effective, simple, and fast diagnostic tool for the detection of MSI with high clinical sensitivity. Additionally, the assay is equally compatible with solid and liquid biopsies, also including samples of cancers with low MSI frequency.

\section{Pancreatic Cancers}

Although pancreatic cancer (PC), is not very frequent, its aggressiveness implies that the ratio of cases per number of deaths is close to 1. Nowadays, it is the seventh leading cause of cancer death worldwide and it has been estimated that it will surpass breast cancer in approximately 5 years [1]. Similar to CRC, the majority of patients are diagnosed with advanced stages and only $10-15 \%$ of PC patients have localized disease at the time of diagnosis [136]. Despite different genetic mutations identified in KRAS, CDKN2A, SMAD4, and TP53 genes, nearly all of them have failed to facilitate a treatment approach and patients continue receiving chemotherapy and radiotherapy depending on tumor stage $[120,137]$.

Recently, the FDA approved olaparib, the first targeted therapy to increase PFS in metastatic PC patients with BRCA germline mutations [138]. 


\subsection{KRAS}

KRAS represents an important biomarker for PC since it appears to be mutated up to $90 \%$. Alterations in this gene tend to be associated with reduced OS, regardless of the PC stage [139]. Several studies have evaluated the role of plasma ctDNA KRAS in the diagnosis, prognosis, and treatment of PC.

It has been observed how KRAS hotspot mutations G12A, G12C, G12D, G12R, G12S, G12V, and G13D detected via multiplex ddPCR were more represented in samples from metastatic PC patients than in locally advanced disease [120-123]. The amount of KRAS mutated ctDNA increases in advanced disease stages and has been significantly associated with the presence of distant organ metastasis [120]. Additionally, plasma ctDNA KRAS mutation incidence has been significantly associated with poor prognosis and OS [124-127]. In a locally advanced unresectable PC cohort, ctDNA KRAS mutation concentration was significantly lower after treatment [140]. In a similar study, researchers observed a better response to therapy in patients with whom KRAS ctDNA was not detectable or had disappeared within 6 months of treatment [128]. These results are in concordance with another study in which a multiplex ddPCR assay was used to detect 16 KRAS mutations (G12A, G12C, G12D, G12F, G12G, G12L, G12R, G12S, G12V and G13A, G13C, G13D, G13G, G13R, G13S, and G13V) (Table 4) and 7 NRAS mutations (Q61R, Q61K, Q61L, Q61H, Q61P, Q61E, and E62K) [123]. Sugimori et al. noted how KRAS mutations were detected at disease progression in some patients, whereas in some of them, the mutations disappeared after chemotherapy treatment. Importantly, in those patients, the mutations appeared at the same time as disease recurrence or even earlier. These findings highlight the predictive value of plasma longitudinal ctDNA monitoring for disease progression and response to treatment in PC patients [123].

As it has been assessed in different tumor types, bloodstream EVs represent an alternative source of ctDNA to provide information on disease evolution. In another study, ddPCR was used to assess KRAS hotspot mutations from EVs-derived DNA and matched cfDNA isolated from PC patients [129]. The sensitivity and specificity were $75.4 \%$ and $92.6 \%$, respectively. Interestingly, KRAS mutation detection in EVs was superior to plasma cfDNA across all stages. Additionally, the observation of mutation rate in the localized pre- and post-resection cohort showed a precipitous decrease from $66 \%$ to $5 \%$, respectively.

\subsection{Others}

Recent studies confirmed the importance of genotyping different mutations in various genes aside from KRAS [141]. ddPCR was used to screen mutations previously identified via NGS in the KRAS, BRCA2 (S2378X), EGFR (R521K), ERBB2 (I655V, P1170A), and KRAS genes in a cohort of metastatic PDAC patients (NCT02017015). As expected, the KRAS mutation rate was $72.3 \%$, whereas $B R C A 2$, EGFR, and $E R B B 2$ were $11.7 \%, 13.3 \%$, and $6.4 \%$, respectively [142]. Other analyses associated the ERBB2 I655V mutation with worse OS among metastatic PC patients. Further analyses are required to determine whether those patients would benefit from targeted therapy using, for example, trastuzumab. These results remark the need for target gene sequencing analysis using ctDNA-based liquid biopsy samples to better guide individualized treatments.

\section{Clinical Trials Using ddPCR}

The potential utility of ddPCR technology in clinical research is shown by the large number of clinical trials and enrolled cancer patients [143]. The growing number of biomarkers, targeted drugs, and immunotherapies have revolutionized patient treatments. However, there is an emerging need for identifying the driver mutations that are involved in treatment response, which is critical for therapeutic decision-making. In Table 5 we explore the clinical trials that are focusing on the ddPCR system to measure and quantify actionable biomarkers before, during, and after cancer treatment. Remarkably, the European Medicines Agency (EMA) includes the use of liquid biopsies for NSCLC management [144]. 
There are several active clinical trials recruiting NSCLC patients, in fact, most of them use the ddPCR method to evaluate the EGFR mutation status, indicating its high clinical significance. In the case of breast cancer, the only ongoing studies enrolled $\mathrm{mBC}$ patients for ESR1 and HER2 analyses. Among people diagnosed with mCRC, ddPCR assesses RAS mutations together with MGMT methylation for response to treatment. Thousands of volunteers would be involved in a prospective study for the detection and tracking of specific mutations in cfDNA isolated from CRC patients.

Table 5. An overview of the ongoing clinical trials in which the dPPCR technique is used for actionable biomarker detection.

\begin{tabular}{|c|c|c|c|c|}
\hline Disease. & Identifier & Aims & State & Number of Patients \\
\hline \multirow{10}{*}{ NSCLC } & NCT04720339 & cfDNA quantification & Recruiting & 250 \\
\hline & NCT02418234 & EGFR T790M monitoring & Completed & 314 \\
\hline & NCT02778854 & Driver mutation detection & Recruiting & 200 \\
\hline & NCT02279004 & $\begin{array}{l}B R A F, K R A S, \text { and } E G F R \\
\text { mutation detection }\end{array}$ & Recruiting & $680 *$ \\
\hline & NCT03771404 & $\begin{array}{l}\text { Study genetic alteration during } \\
\text { the follow-up }\end{array}$ & Recruiting & 50 \\
\hline & NCT03265496 & $\begin{array}{l}\text { EGFR detection in solid and } \\
\text { liquid biopsies }\end{array}$ & Active, not recruiting & 117 \\
\hline & NCT03706625 & $\begin{array}{c}\text { Biomarker discovery in ctDNA } \\
\text { and CTCs }\end{array}$ & Recruiting & $170 *$ \\
\hline & NCT03865511 & $E G F R$ in ctDNA & Recruiting & 150 \\
\hline & NCT04814407 & $\begin{array}{c}\text { Immune-methylated signature } \\
\text { identification }\end{array}$ & Recruiting & 900 \\
\hline & NCT01930474 & EGFR and ALK & Unknown & 200 \\
\hline \multirow{5}{*}{ Advanced NSCLC } & NCT03309462 & EGFR in tissue and plasma & Completed & 50 \\
\hline & NCT02282267 & EGFR in plasma cfDNA & Unknown & 188 \\
\hline & NCT02511288 & Genetic profile ctDNA & Recruiting & 900 \\
\hline & NCT02997501 & $\begin{array}{l}\text { EGFR T790M comparison between } \\
\text { COBAS, ddPCR and NGS }\end{array}$ & Completed & 167 \\
\hline & NCT04912687 & EGFR mutation & Not yet recruiting & 580 \\
\hline SCC Lung & NCT03938012 & MET N375S, TP53 & Recruiting & 80 \\
\hline \multirow{7}{*}{$\mathrm{mBC}$} & NCT02913430 & ESR1 mutation & Active, not recruiting & 7 \\
\hline & NCT04720729 & $\begin{array}{c}\text { Chemotherapy monitoring } \\
\text { ctDNA HER2 }\end{array}$ & Recruiting & 214 \\
\hline & NCT04480814 & PIK3CA in ER+/HER2 & Recruiting & 120 \\
\hline & NCT03947736 & ctDNA HER2 amplification & Recruiting & 200 \\
\hline & NCT03829306 & Mechanism of Kadcyla resistance & Recruiting & 50 \\
\hline & NCT03357120 & $\begin{array}{l}\text { ctDNA after neoadjuvant } \\
\text { chemotherapy }\end{array}$ & Recruiting & 180 \\
\hline & NCT02473120 & ESR1 mutations & Completed & 104 \\
\hline \multirow{4}{*}{$\mathrm{mCRC}$} & NCT02994888 & ctDNA for cetuximab monitoring & Completed & 47 \\
\hline & NCT03832621 & MGMT methylation & Active & 135 \\
\hline & NCT04554836 & $R A S$ mutation monitoring & Recruiting & 144 \\
\hline & NCT03227926 & $R A S$ mutation monitoring & Recruiting & 129 \\
\hline CRC & NCT04050345 & $\begin{array}{c}\text { KRAS, NRAS, BRAF, PIK3CA, TP53 } \\
\text { and APC detection }\end{array}$ & Recruiting & 1000 \\
\hline
\end{tabular}

* The study includes participants diagnosed with other cancer types. 


\section{Conclusions}

Liquid biopsies are considered a good alternative and complementary tool for cancer management. The study of specific biomarkers by high throughput techniques could guide clinicians in the monitoring of disease evolution during the administration of targeted therapies. Although ddPCR has demonstrated its high sensitivity and specificity rates for detecting rare actionable mutations, further studies are required to implement it in all clinical laboratories for precision medicine.

Author Contributions: Conceptualization, I.P.-A. and N.G.-R.; writing—original draft preparation, I.P.-A. and A.A.-P.; writing-review and editing, N.G.-R., J.C.-N., V.G.-R. and Á.A.-S.; project administration, V.G.-R. and Á.A.-S.; funding Á.A.-S. All authors have read and agreed to the published version of the manuscript.

Funding: This research was funded by grants from the "Fondo de Investigaciones Sanitarias" (FIS) (PI17/01489), the Ministerio de Economía y Competitividad-FEDER (RTC-2019-6918-1), and Comunidad de Madrid (INDB2019/BMD-17222).

Conflicts of Interest: The authors declare no conflict of interest.

\section{References}

1. Sung, H.; Ferlay, J.; Siegel, R.L.; Laversanne, M.; Soerjomataram, I.; Jemal, A.; Bray, F. Global cancer statistics 2020: GLOBOCAN estimates of incidence and mortality worldwide for 36 cancers in 185 countries. CA Cancer J. Clin. 2021, 68, caac-21660. [CrossRef]

2. Global Cancer Observatory. Available online: https://gco.iarc.fr/ (accessed on 28 June 2021).

3. Lauby-Secretan, B.; Scoccianti, C.; Loomis, D.; Benbrahim-Tallaa, L.; Bouvard, V.; Bianchini, F.; Straif, K. Breast-Cancer Screening - Viewpoint of the IARC Working Group. N. Engl. J. Med. 2015, 372, 2353-2358. [CrossRef]

4. Lauby-Secretan, B.; Vilahur, N.; Bianchini, F.; Guha, N.; Straif, K. The IARC Perspective on Colorectal Cancer Screening. N. Engl. J. Med. 2018, 378, 1734-1740. [CrossRef]

5. Hüsing, A.; Kaaks, R. Risk prediction models versus simplified selection criteria to determine eligibility for lung cancer screening: An analysis of German federal-wide survey and incidence data. Eur. J. Epidemiol. 2020, 35, 899-912. [CrossRef] [PubMed]

6. Siravegna, G.; Marsoni, S.; Siena, S.; Bardelli, A. Integrating liquid biopsies into the management of cancer. Nat. Rev. Clin. Oncol. 2017, 14, 531-548. [CrossRef]

7. Russano, M.; Napolitano, A.; Ribelli, G.; Iuliani, M.; Simonetti, S.; Citarella, F.; Pantano, F.; Dell'Aquila, E.; Anesi, C.; Silvestris, N.; et al. Liquid biopsy and tumor heterogeneity in metastatic solid tumors: The potentiality of blood samples. J. Exp. Clin. Cancer Res. 2020, 39, 120. [CrossRef] [PubMed]

8. Fernández-Lázaro, D.; García Hernández, J.L.; García, A.C.; Córdova Martínez, A.; Mielgo-Ayuso, J.; Cruz-Hernández, J.J. Liquid Biopsy as Novel Tool in Precision Medicine: Origins, Properties, Identification and Clinical Perspective of Cancer's Biomarkers. Diagnostics 2020, 10, 215. [CrossRef] [PubMed]

9. Palmirotta, R.; Lovero, D.; Cafforio, P.; Felici, C.; Mannavola, F.; Pellè, E.; Quaresmini, D.; Tucci, M.; Silvestris, F. Liquid biopsy of cancer: A multimodal diagnostic tool in clinical oncology. Ther. Adv. Med. Oncol. 2018, 10, 175883591879463. [CrossRef]

10. Russo, A.; Incorvaia, L.; Del Re, M.; Malapelle, U.; Capoluongo, E.; Gristina, V.; Castiglia, M.; Danesi, R.; Fassan, M.; Giuffrè, G.; et al. The molecular profiling of solid tumors by liquid biopsy: A position paper of the AIOM-SIAPEC-IAP-SIBioC-SIC-SIF Italian Scientific Societies. ESMO Open 2021, 6, 100164. [CrossRef] [PubMed]

11. Vendrell, J.; Mau-Them, F.; Béganton, B.; Godreuil, S.; Coopman, P.; Solassol, J. Circulating Cell Free Tumor DNA Detection as a Routine Tool forLung Cancer Patient Management. Int. J. Mol. Sci. 2017, 18, 264. [CrossRef]

12. Singh, R.R. Next-Generation Sequencing in High-Sensitive Detection of Mutations in Tumors. J. Mol. Diagn. 2020, 22, 994-1007. [CrossRef] [PubMed]

13. Abnizova, I.; Boekhorst, R.T.; Orlov, Y.L. Computational Errors and Biases in Short Read Next Generation Sequencing. J. Proteomics Bioinform. 2017, 10, 1-17. [CrossRef]

14. Vogelstein, B.; Kinzler, K.W. Digital PCR. Proc. Natl. Acad. Sci. USA 1999, 96, 9236-9241. [CrossRef]

15. Cabel, L.; Proudhon, C.; Romano, E.; Girard, N.; Lantz, O.; Stern, M.-H.; Pierga, J.-Y.; Bidard, F.-C. Clinical potential of circulating tumour DNA in patients receiving anticancer immunotherapy. Nat. Rev. Clin. Oncol. 2018, 15, 639-650. [CrossRef]

16. Postel, M.; Roosen, A.; Laurent-Puig, P.; Taly, V.; Wang-Renault, S.-F. Droplet-based digital PCR and next generation sequencing for monitoring circulating tumor DNA: A cancer diagnostic perspective. Expert Rev. Mol. Diagn. 2018, 18, 7-17. [CrossRef] [PubMed]

17. Thress, K.S.; Brant, R.; Carr, T.H.; Dearden, S.; Jenkins, S.; Brown, H.; Hammett, T.; Cantarini, M.; Barrett, J.C. EGFR mutation detection in ctDNA from NSCLC patient plasma: A cross-platform comparison of leading technologies to support the clinical development of AZD9291. Lung Cancer 2015, 90, 509-515. [CrossRef] [PubMed] 
18. Freidin, M.B.; Freydina, D.V.; Leung, M.; Montero Fernandez, A.; Nicholson, A.G.; Lim, E. Circulating Tumor DNA Outperforms Circulating Tumor Cells for KRAS Mutation Detection in Thoracic Malignancies. Clin. Chem. 2015, 61, 1299-1304. [CrossRef] [PubMed]

19. Oxnard, G.R.; Paweletz, C.P.; Kuang, Y.; Mach, S.L.; O'Connell, A.; Messineo, M.M.; Luke, J.J.; Butaney, M.; Kirschmeier, P.; Jackman, D.M.; et al. Noninvasive Detection of Response and Resistance in EGFR -Mutant Lung Cancer Using Quantitative Next-Generation Genotyping of Cell-Free Plasma DNA. Clin. Cancer Res. 2014, 20, 1698-1705. [CrossRef]

20. Uchida, J.; Kato, K.; Kukita, Y.; Kumagai, T.; Nishino, K.; Daga, H.; Nagatomo, I.; Inoue, T.; Kimura, M.; Oba, S.; et al. Diagnostic Accuracy of Noninvasive Genotyping of EGFR in Lung Cancer Patients by Deep Sequencing of Plasma Cell-Free DNA. Clin. Chem. 2015, 61, 1191-1196. [CrossRef] [PubMed]

21. Narayan, A.; Carriero, N.J.; Gettinger, S.N.; Kluytenaar, J.; Kozak, K.R.; Yock, T.I.; Muscato, N.E.; Ugarelli, P.; Decker, R.H.; Patel, A.A. Ultrasensitive Measurement of Hotspot Mutations in Tumor DNA in Blood Using Error-Suppressed Multiplexed Deep Sequencing. Cancer Res. 2012, 72, 3492-3498. [CrossRef]

22. Olmedillas-López, S.; García-Arranz, M.; García-Olmo, D. Current and Emerging Applications of Droplet Digital PCR in Oncology. Mol. Diagn. Ther. 2017, 21, 493-510. [CrossRef]

23. Griffin, R.; Ramirez, R.A. Molecular Targets in Non-Small Cell Lung Cancer. Ochsner J. 2017, 17, 388-392. [CrossRef]

24. Pennell, N.A.; Arcila, M.E.; Gandara, D.R.; West, H. Biomarker Testing for Patients with Advanced Non-Small Cell Lung Cancer: Real-World Issues and Tough Choices. Am. Soc. Clin. Oncol. Educ. Book 2019, 531-542. [CrossRef]

25. Wadowska, K.; Bil-Lula, I.; Trembecki, Ł.; Śliwińska-Mossoń, M. Genetic Markers in Lung Cancer Diagnosis: A Review. Int. J. Mol. Sci. 2020, 21, 4569. [CrossRef] [PubMed]

26. Hellmann, M.D.; Ciuleanu, T.-E.; Pluzanski, A.; Lee, J.S.; Otterson, G.A.; Audigier-Valette, C.; Minenza, E.; Linardou, H.; Burgers, S.; Salman, P.; et al. Nivolumab plus Ipilimumab in Lung Cancer with a High Tumor Mutational Burden. N. Engl. J. Med. 2018, 378, 2093-2104. [CrossRef]

27. Vannitamby, A.; Hendry, S.; Irving, L.; Steinfort, D.; Bozinovski, S. Novel multiplex droplet digital PCR assay for scoring PD-L1 in non-small cell lung cancer biopsy specimens. Lung Cancer 2019, 134, 233-237. [CrossRef]

28. Mellert, H.S.; Jackson, L.; Pestano, G.A. Performance verification of a plasma-based PD-L1 test that reliably measures mRNA expression from patients with NCSLC. J. Clin. Oncol. 2018, 36, 156-156. [CrossRef]

29. Ettinger, D.S.; Wood, D.E.; Aggarwal, C.; Aisner, D.L.; Akerley, W.; Bauman, J.R.; Bharat, A.; Bruno, D.S.; Chang, J.Y.; Chirieac, L.R.; et al. NCCN Guidelines Insights: Non-Small Cell Lung Cancer, Version 1.2020. J. Natl. Compr. Cancer Netw. 2019, 17, 1464-1472. [CrossRef] [PubMed]

30. Santoni-Rugiu; Melchior; Urbanska; Jakobsen; Stricker; Grauslund; Sørensen Intrinsic resistance to EGFR-Tyrosine Kinase Inhibitors in EGFR-Mutant Non-Small Cell Lung Cancer: Differences and Similarities with Acquired Resistance. Cancers 2019, 11, 923. [CrossRef] [PubMed]

31. Harrison, P.T.; Vyse, S.; Huang, P.H. Rare epidermal growth factor receptor (EGFR) mutations in non-small cell lung cancer. Semin. Cancer Biol. 2020, 61, 167-179. [CrossRef] [PubMed]

32. De Kock, R.; Deiman, B.; Kraaijvanger, R.; Scharnhorst, V. Optimized (Pre) Analytical Conditions and Workflow for Droplet Digital PCR Analysis of Cell-Free DNA from Patients with Suspected Lung Carcinoma. J. Mol. Diagn. 2019, 21, 895-902. [CrossRef] [PubMed]

33. Gelatti, A.C.Z.; Drilon, A.; Santini, F.C. Optimizing the sequencing of tyrosine kinase inhibitors (TKIs) in epidermal growth factor receptor (EGFR) mutation-positive non-small cell lung cancer (NSCLC). Lung Cancer 2019, 137, 113-122. [CrossRef] [PubMed]

34. Bordi, P.; Del Re, M.; Minari, R.; Rofi, E.; Buti, S.; Restante, G.; Squadrilli, A.; Crucitta, S.; Casartelli, C.; Gnetti, L.; et al. From the beginning to resistance: Study of plasma monitoring and resistance mechanisms in a cohort of patients treated with osimertinib for advanced T790M-positive NSCLC. Lung Cancer 2019, 131, 78-85. [CrossRef]

35. Spence, T.; Perera, S.; Weiss, J.; Grenier, S.; Ranich, L.; Shepherd, F.; Stockley, T.L. Clinical implementation of circulating tumour DNA testing for EGFR T790M for detection of treatment resistance in non-small cell lung cancer. J. Clin. Pathol. 2021, 74, 91-97. [CrossRef]

36. Silveira, C.; Sousa, A.C.; Janeiro, A.; Malveiro, S.; Teixeira, E.; Brysch, E.; Pantarotto, M.; Felizardo, M.; Madureira, R.; Nogueira, F.; et al. Detection and quantification of EGFR T790M mutation in liquid biopsies by droplet digital PCR. Transl. Lung Cancer Res. 2021, 10, 1200-1208. [CrossRef]

37. Buder, A.; Hochmair, M.J.; Filipits, M. The Allele Frequency of EGFR Mutations Predicts Survival in Advanced EGFR T790MPositive Non-small Cell Lung Cancer Patients Treated with Osimertinib. Target. Oncol. 2021, 16, 77-84. [CrossRef] [PubMed]

38. Li, J.Y.C.; Ho, J.C.M.; Wong, K.H. T790M mutant copy number quantified via ddPCR predicts outcome after osimertinib treatment in lung cancer. Oncotarget 2018, 9, 27929-27939. [CrossRef] [PubMed]

39. Buder, A.; Hochmair, M.J.; Schwab, S.; Bundalo, T.; Schenk, P.; Errhalt, P.; Mikes, R.E.; Absenger, G.; Patocka, K.; Baumgartner, B.; et al. Cell-Free Plasma DNA-Guided Treatment with Osimertinib in Patients with Advanced EGFR-Mutated NSCLC. J. Thorac. Oncol. 2018, 13, 821-830. [CrossRef] [PubMed]

40. Romero, A.; Serna-Blasco, R.; Alfaro, C.; Sánchez-Herrero, E.; Barquín, M.; Turpin, M.C.; Chico, S.; Sanz-Moreno, S.; RodrigezFesta, A.; Laza-Briviesca, R.; et al. ctDNA analysis reveals different molecular patterns upon disease progression in patients treated with osimertinib. Transl. Lung Cancer Res. 2020, 9, 532-540. [CrossRef] [PubMed] 
41. Ariyasu, R.; Uchibori, K.; Sasaki, T.; Tsukahara, M.; Kiyotani, K.; Yoshida, R.; Ono, Y.; Kitazono, S.; Ninomiya, H.; Ishikawa, Y.; et al. Monitoring epidermal growth factor receptor C797S mutation in Japanese non-small cell lung cancer patients with serial cell-free DNA evaluation using digital droplet PCR. Cancer Sci. 2021, 112, 2371-2380. [CrossRef] [PubMed]

42. Leonetti, A.; Sharma, S.; Minari, R.; Perego, P.; Giovannetti, E.; Tiseo, M. Resistance mechanisms to osimertinib in EGFR-mutated non-small cell lung cancer. Br. J. Cancer 2019, 121, 725-737. [CrossRef] [PubMed]

43. Pakkala, S.; Ramalingam, S.S. Personalized therapy for lung cancer: Striking a moving target. JCI Insight 2018, 3, 1-14. [CrossRef] [PubMed]

44. Esteva-Socias, M.; Enver-Sumaya, M.; Gómez-Bellvert, C.; Guillot, M.; Azkárate, A.; Marsé, R.; Sastre, Ú.S.; Blasco, A.; CalabuigFariñas, S.; Asensio, V.J.; et al. Detection of the EGFR G719S Mutation in Non-small Cell Lung Cancer Using Droplet Digital PCR. Front. Med. 2020, 7, 1-7. [CrossRef] [PubMed]

45. Carvalho, A.S.; Cuco, C.M.; Lavareda, C.; Miguel, F.; Ventura, M.; Almeida, S.; Pinto, P.; de Abreu, T.T.; Rodrigues, L.V.; Seixas, S.; et al. Bronchoalveolar Lavage Proteomics in Patients with Suspected Lung Cancer. Sci. Rep. 2017, 7, 42190. [CrossRef]

46. Lee, S.H.; Kim, E.Y.; Kim, T.; Chang, Y.S. Compared to plasma, bronchial washing fluid shows higher diagnostic yields for detecting EGFR-TKI sensitizing mutations by ddPCR in lung cancer. Respir. Res. 2020, 21, 1-8. [CrossRef]

47. Hannigan, B.; Ye, W.; Mehrotra, M.; Lam, V.; Bolivar, A.; Zalles, S.; Barkoh, B.A.; Duose, D.; Hu, P.C.; Broaddus, R.; et al. Liquid biopsy assay for lung carcinoma using centrifuged supernatants from fine-needle aspiration specimens. Ann. Oncol. 2019, 30, 963-969. [CrossRef]

48. Isaka, T.; Yokose, T.; Ito, H.; Nakayama, H.; Miyagi, Y.; Saito, H.; Masuda, M. Detection of EGFR mutation of pulmonary adenocarcinoma in sputum using droplet digital PCR. BMC Pulm. Med. 2021, 21, 1-11. [CrossRef]

49. Chen, S.; Zhao, J.; Cui, L.; Liu, Y. Urinary circulating DNA detection for dynamic tracking of EGFR mutations for NSCLC patients treated with EGFR-TKIs. Clin. Transl. Oncol. 2017, 19, 332-340. [CrossRef]

50. Liu, Y.; Yang, S.; Zhao, J.; He, Z.; Ma, J.; Guo, Y.; Wang, W.; Yoshizawa, A.; Prelaj, A.; Tiseo, M.; et al. Cell-free DNA from cerebrospinal fluid can be used to detect the EGFR mutation status of lung adenocarcinoma patients with central nervous system metastasis. Transl. Lung Cancer Res. 2021, 10, 914-925. [CrossRef]

51. Wahl, S.G.F.; Dai, H.Y.; Emdal, E.F.; Ottestad, A.L.; Dale, V.G.; Richardsen, E.; Halvorsen, T.O.; Grønberg, B.H. Prognostic value of absolute quantification of mutated KRAS in circulating tumour DNA in lung adenocarcinoma patients prior to therapy. J. Pathol. Clin. Res. 2021, 7, 209-219. [CrossRef]

52. Michaelidou, K.; Koutoulaki, C.; Mavridis, K.; Vorrias, E.; Papadaki, M.A.; Koutsopoulos, A.V.; Mavroudis, D.; Agelaki, S. Detection of KRAS G12/G13 Mutations in Cell Free-DNA by Droplet Digital PCR, Offers Prognostic Information for Patients with Advanced Non-Small Cell Lung Cancer. Cells 2020, 9, 2514. [CrossRef]

53. Román, M.; Baraibar, I.; López, I.; Nadal, E.; Rolfo, C.; Vicent, S.; Gil-Bazo, I. KRAS oncogene in non-small cell lung cancer: Clinical perspectives on the treatment of an old target. Mol. Cancer 2018, 17, 33. [CrossRef]

54. Sidaway, P. Sotorasib effective in KRAS-mutant NSCLC. Nat. Rev. Clin. Oncol. 2021, 18, 470. [CrossRef] [PubMed]

55. Skoulidis, F.; Li, B.T.; Dy, G.K.; Price, T.J.; Falchook, G.S.; Wolf, J.; Italiano, A.; Schuler, M.; Borghaei, H.; Barlesi, F.; et al. Sotorasib for Lung Cancers with KRAS p.G12C Mutation. N. Engl. J. Med. 2021, 384, 2371-2381. [CrossRef] [PubMed]

56. Fu, Y.; Wang, A.; Zhou, J.; Feng, W.; Shi, M.; Xu, X.; Zhao, H.; Cai, L.; Feng, J.; Lv, X.; et al. Advanced NSCLC Patients with EGFR T790M Harboring TP53 R273C or KRAS G12V Cannot Benefit From Osimertinib Based on a Clinical Multicentre Study by Tissue and Liquid Biopsy. Front. Oncol. 2021, 11, 1-10. [CrossRef]

57. Lee, M.-H.; Yanagawa, J.; Li, R.; Walser, T.C.; Krysan, K.; Wang, G.; Goldman, J.W.; Garon, E.B.G.; Zeng, G.; Sharma, S.; et al. Increased PD-L1 expression in KRAS mutated premalignant human bronchial epithelial cells is enhanced by LKB1 loss and mediated by ERK activation. J. Immunother. Cancer 2015, 3, P305. [CrossRef]

58. Chaft, J.E.; Rusch, V.; Ginsberg, M.S.; Paik, P.K.; Finley, D.J.; Kris, M.G.; Price, K.A.R.; Azzoli, C.G.; Fury, M.G.; Riely, G.J.; et al. Phase II Trial of Neoadjuvant Bevacizumab Plus Chemotherapy and Adjuvant Bevacizumab in Patients with Resectable Nonsquamous Non-Small-Cell Lung Cancers. J. Thorac. Oncol. 2013, 8, 1084-1090. [CrossRef]

59. Isaksson, S.; George, A.M.; Jönsson, M.; Cirenajwis, H.; Jönsson, P.; Bendahl, P.-O.; Brunnström, H.; Staaf, J.; Saal, L.H.; Planck, M. Pre-operative plasma cell-free circulating tumor DNA and serum protein tumor markers as predictors of lung adenocarcinoma recurrence. Acta Oncol. 2019, 58, 1079-1086. [CrossRef] [PubMed]

60. Sacher, A.G.; Paweletz, C.; Dahlberg, S.E.; Alden, R.S.; O'Connell, A.; Feeney, N.; Mach, S.L.; Jänne, P.A.; Oxnard, G.R. Prospective Validation of Rapid Plasma Genotyping for the Detection of EGFR and KRAS Mutations in Advanced Lung Cancer. JAMA Oncol. 2016, 2, 1014. [CrossRef]

61. Zulato, E.; Attili, I.; Pavan, A.; Nardo, G.; Del Bianco, P.; Boscolo Bragadin, A.; Verza, M.; Pasqualini, L.; Pasello, G.; Fassan, M.; et al. Early assessment of KRAS mutation in cfDNA correlates with risk of progression and death in advanced non-small-cell lung cancer. Br. J. Cancer 2020, 123, 81-91. [CrossRef]

62. Guibert, N.; Pradines, A.; Farella, M.; Casanova, A.; Gouin, S.; Keller, L.; Favre, G.; Mazieres, J. Monitoring KRAS mutations in circulating DNA and tumor cells using digital droplet PCR during treatment of KRAS -mutated lung adenocarcinoma. Lung Cancer 2016, 100, 1-4. [CrossRef] [PubMed]

63. Duma, N.; Santana-Davila, R.; Molina, J.R. Non-Small Cell Lung Cancer: Epidemiology, Screening, Diagnosis, and Treatment. Mayo Clin. Proc. 2019, 94, 1623-1640. [CrossRef] 
64. Lund, H.L.; Hughesman, C.B.; Fakhfakh, K.; McNeil, K.; Clemens, S.; Hocken, K.; Pettersson, R.; Karsan, A.; Foster, L.J.; Haynes, C. Initial Diagnosis of ALK-Positive Non-Small-Cell Lung Cancer Based on Analysis of ALK Status Utilizing Droplet Digital PCR. Anal. Chem. 2016, 88, 4879-4885. [CrossRef] [PubMed]

65. Liu, Y.; Wu, S.; Shi, X.; Liang, Z.; Zeng, X. ALK detection in lung cancer: Identification of atypical and cryptic ALK rearrangements using an optimal algorithm. J. Cancer Res. Clin. Oncol. 2020, 146, 1307-1320. [CrossRef] [PubMed]

66. Solomon, B.J.; Mok, T.; Kim, D.-W.; Wu, Y.-L.; Nakagawa, K.; Mekhail, T.; Felip, E.; Cappuzzo, F.; Paolini, J.; Usari, T.; et al. First-Line Crizotinib versus Chemotherapy in ALK -Positive Lung Cancer. N. Engl. J. Med. 2014, 371, 2167-2177. [CrossRef]

67. Sharma, G.G.; Mota, I.; Mologni, L.; Patrucco, E.; Gambacorti-Passerini, C.; Chiarle, R. Tumor resistance against ALK targeted therapy-Where it comes from and where it goes. Cancers 2018, 10, 62. [CrossRef]

68. Kodama, T.; Tsukaguchi, T.; Yoshida, M.; Kondoh, O.; Sakamoto, H. Selective ALK inhibitor alectinib with potent antitumor activity in models of crizotinib resistance. Cancer Lett. 2014, 351, 215-221. [CrossRef] [PubMed]

69. Toyokawa, G.; Seto, T. Updated evidence on the mechanisms of resistance to ALK inhibitors and strategies to overcome such resistance: Clinical and preclinical data. Oncol. Res. Treat. 2015, 38, 291-298. [CrossRef]

70. Noé, J.; Lovejoy, A.; Ou, S.H.I.; Yaung, S.J.; Bordogna, W.; Klass, D.M.; Cummings, C.A.; Shaw, A.T. ALK Mutation Status Before and After Alectinib Treatment in Locally Advanced or Metastatic ALK-Positive NSCLC: Pooled Analysis of Two Prospective Trials. J. Thorac. Oncol. 2020, 15, 601-608. [CrossRef]

71. Yoshida, R.; Sasaki, T.; Umekage, Y.; Tanno, S.; Ono, Y.; Ogata, M.; Chiba, S.; Mizukami, Y.; Ohsaki, Y. Highly sensitive detection of ALK resistance mutations in plasma using droplet digital PCR. BMC Cancer 2018, 18, 1-8. [CrossRef]

72. Harbeck, N.; Penault-Llorca, F.; Cortes, J.; Gnant, M.; Houssami, N.; Poortmans, P.; Ruddy, K.; Tsang, J.; Cardoso, F. Breast cancer. Nat. Rev. Dis. Prim. 2019, 5, 66. [CrossRef]

73. Zivanovic Bujak, A.; Weng, C.-F.; Silva, M.J.; Yeung, M.; Lo, L.; Ftouni, S.; Litchfield, C.; Ko, Y.-A.; Kuykhoven, K.; Van Geelen, C.; et al. Circulating tumour DNA in metastatic breast cancer to guide clinical trial enrolment and precision oncology: A cohort study. PLOS Med. 2020, 17, e1003363. [CrossRef] [PubMed]

74. Beaver, J.A.; Jelovac, D.; Balukrishna, S.; Cochran, R.L.; Croessmann, S.; Zabransky, D.J.; Wong, H.Y.; Valda Toro, P.; Cidado, J.; Blair, B.G.; et al. Detection of Cancer DNA in Plasma of Patients with Early-Stage Breast Cancer. Clin. Cancer Res. 2014, 20, 2643-2650. [CrossRef] [PubMed]

75. Olsson, E.; Winter, C.; George, A.; Chen, Y.; Howlin, J.; Tang, M.E.; Dahlgren, M.; Schulz, R.; Grabau, D.; Westen, D.; et al. Serial monitoring of circulating tumor DNA in patients with primary breast cancer for detection of occult metastatic disease. $E M B O$ Mol. Med. 2015, 7, 1034-1047. [CrossRef]

76. Dawson, S.-J.; Tsui, D.W.Y.; Murtaza, M.; Biggs, H.; Rueda, O.M.; Chin, S.-F.; Dunning, M.J.; Gale, D.; Forshew, T.; Mahler-Araujo, B.; et al. Analysis of Circulating Tumor DNA to Monitor Metastatic Breast Cancer. N. Engl. J. Med. 2013, 368, 1199-1209. [CrossRef]

77. Sluiter, M.D.; van Rensburg, E.J. Large genomic rearrangements of the BRCA1 and BRCA2 genes: Review of the literature and report of a novel BRCA1 mutation. Breast Cancer Res. Treat. 2011, 125, 325-349. [CrossRef] [PubMed]

78. Preobrazhenskaya, E.V.; Bizin, I.V.; Kuligina, E.S.; Shleykina, A.Y.; Suspitsin, E.N.; Zaytseva, O.A.; Anisimova, E.I.; Laptiev, S.A.; Gorodnova, T.V.; Belyaev, A.M.; et al. Detection of BRCA1 gross rearrangements by droplet digital PCR. Breast Cancer Res. Treat. 2017, 165, 765-770. [CrossRef]

79. Oscorbin, I.; Kechin, A.; Boyarskikh, U.; Filipenko, M. Multiplex ddPCR assay for screening copy number variations in BRCA1 gene. Breast Cancer Res. Treat. 2019, 178, 545-555. [CrossRef]

80. Jacot, W.; Dalenc, F.; Lopez-Crapez, E.; Chaltiel, L.; Durigova, A.; Gros, N.; Lozano, N.; Lacaze, J.-L.; Pouderoux, S.; Gladieff, L.; et al. PIK3CA mutations early persistence in cell-free tumor DNA as a negative prognostic factor in metastatic breast cancer patients treated with hormonal therapy. Breast Cancer Res. Treat. 2019, 177, 659-667. [CrossRef]

81. André, F.; Ciruelos, E.; Rubovszky, G.; Campone, M.; Loibl, S.; Rugo, H.S.; Iwata, H.; Conte, P.; Mayer, I.A.; Kaufman, B.; et al. Alpelisib for PIK3CA -Mutated, Hormone Receptor-Positive Advanced Breast Cancer. N. Engl. J. Med. 2019, 380, 1929-1940. [CrossRef]

82. O'Leary, B.; Hrebien, S.; Morden, J.P.; Beaney, M.; Fribbens, C.; Huang, X.; Liu, Y.; Bartlett, C.H.; Koehler, M.; Cristofanilli, M.; et al. Early circulating tumor DNA dynamics and clonal selection with palbociclib and fulvestrant for breast cancer. Nat. Commun. 2018, 9, 896. [CrossRef]

83. Moynahan, M.E.; Chen, D.; He, W.; Sung, P.; Samoila, A.; You, D.; Bhatt, T.; Patel, P.; Ringeisen, F.; Hortobagyi, G.N.; et al. Correlation between PIK3CA mutations in cell-free DNA and everolimus efficacy in HR+, HER2- advanced breast cancer: Results from BOLERO-2. Br. J. Cancer 2017, 116, 726-730. [CrossRef]

84. Takeshita, T.; Yamamoto, Y.; Yamamoto-Ibusuki, M.; Tomiguchi, M.; Sueta, A.; Murakami, K.; Omoto, Y.; Iwase, H. Analysis of ESR1 and PIK3CA mutations in plasma cell-free DNA from ER-positive breast cancer patients. Oncotarget 2017, 8, 52142-52155. [CrossRef]

85. Toy, W.; Shen, Y.; Won, H.; Green, B.; Sakr, R.A.; Will, M.; Li, Z.; Gala, K.; Fanning, S.; King, T.A.; et al. ESR1 ligand-binding domain mutations in hormone-resistant breast cancer. Nat. Genet. 2013, 45, 1439-1445. [CrossRef]

86. Toy, W.; Weir, H.; Razavi, P.; Lawson, M.; Goeppert, A.U.; Mazzola, A.M.; Smith, A.; Wilson, J.; Morrow, C.; Wong, W.L.; et al. Activating ESR1 Mutations Differentially Affect the Efficacy of ER Antagonists. Cancer Discov. 2017, 7, 277-287. [CrossRef] [PubMed] 
87. Guttery, D.S.; Page, K.; Hills, A.; Woodley, L.; Marchese, S.D.; Rghebi, B.; Hastings, R.K.; Luo, J.; Pringle, J.H.; Stebbing, J.; et al. Noninvasive Detection of Activating Estrogen Receptor 1 (ESR1) Mutations in Estrogen Receptor-Positive Metastatic Breast Cancer. Clin. Chem. 2015, 61, 974-982. [CrossRef]

88. Lupini, L.; Moretti, A.; Bassi, C.; Schirone, A.; Pedriali, M.; Querzoli, P.; Roncarati, R.; Frassoldati, A.; Negrini, M. High-sensitivity assay for monitoring ESR1 mutations in circulating cell-free DNA of breast cancer patients receiving endocrine therapy. Sci. Rep. 2018, 8, 4371. [CrossRef] [PubMed]

89. Urso, L.; Vernaci, G.; Carlet, J.; Lo Mele, M.; Fassan, M.; Zulato, E.; Faggioni, G.; Menichetti, A.; Di Liso, E.; Griguolo, G.; et al. ESR1 Gene Mutation in Hormone Receptor-Positive HER2-Negative Metastatic Breast Cancer Patients: Concordance Between Tumor Tissue and Circulating Tumor DNA Analysis. Front. Oncol. 2021, 11, 625636. [CrossRef]

90. Chandarlapaty, S.; Chen, D.; He, W.; Sung, P.; Samoila, A.; You, D.; Bhatt, T.; Patel, P.; Voi, M.; Gnant, M.; et al. Prevalence of ESR1 Mutations in Cell-Free DNA and Outcomes in Metastatic Breast Cancer. JAMA Oncol. 2016, 2, 1310. [CrossRef] [PubMed]

91. Takeshita, T.; Yamamoto, Y.; Yamamoto-Ibusuki, M.; Inao, T.; Sueta, A.; Fujiwara, S.; Omoto, Y.; Iwase, H. Clinical significance of monitoring ESR1 mutations in circulating cell-free DNA in estrogen receptor positive breast cancer patients. Oncotarget 2016, 7, 32504-32518. [CrossRef]

92. Jeannot, E.; Darrigues, L.; Michel, M.; Stern, M.-H.; Pierga, J.-Y.; Rampanou, A.; Melaabi, S.; Benoist, C.; Bièche, I.; VincentSalomon, A.; et al. A single droplet digital PCR for ESR1 activating mutations detection in plasma. Oncogene 2020, 39, 2987-2995. [CrossRef]

93. Najim, O.; Huizing, M.; Papadimitriou, K.; Trinh, X.B.; Pauwels, P.; Goethals, S.; Zwaenepoel, K.; Peterson, K.; Weyler, J.; Altintas, S.; et al. The prevalence of estrogen receptor-1 mutation in advanced breast cancer: The estrogen receptor one study (EROS1). Cancer Treat. Res. Commun. 2019, 19, 100123. [CrossRef]

94. Ran, R.; Huang, W.; Liu, Y.; Shao, L.; Liu, X.; Niu, Y.; Kong, W.; Bo, S.; Rugo, H.S.; Lu, S.; et al. Prognostic Value of Plasma HER2 Gene Copy Number in HER2-Positive Metastatic Breast Cancer Treated with First-Line Trastuzumab. Onco Targets. Ther. 2020, 13, 4385-4395. [CrossRef]

95. Gevensleben, H.; Garcia-Murillas, I.; Graeser, M.K.; Schiavon, G.; Osin, P.; Parton, M.; Smith, I.E.; Ashworth, A.; Turner, N.C. Noninvasive Detection of HER2 Amplification with Plasma DNA Digital PCR. Clin. Cancer Res. 2013, 19, 3276-3284. [CrossRef]

96. Garcia-Murillas, I.; Lambros, M.; Turner, N.C. Determination of HER2 Amplification Status on Tumour DNA by Digital PCR. PLoS ONE 2013, 8, e83409. [CrossRef]

97. Garcia-Murillas, I.; Turner, N.C. Assessing HER2 Amplification in Plasma cfDNA. In Methods in Molecular Biology; Institute of Cancer Research: London, UK, 2018; Volume 1768, pp. 161-172, ISBN 9781493977789.

98. Hrebien, S.; O’Leary, B.; Beaney, M.; Schiavon, G.; Fribbens, C.; Bhambra, A.; Johnson, R.; Garcia-Murillas, I.; Turner, N. Reproducibility of Digital PCR Assays for Circulating Tumor DNA Analysis in Advanced Breast Cancer. PLoS ONE 2016, 11, e0165023. [CrossRef] [PubMed]

99. Luo, M.; Clouthier, S.G.; Deol, Y.; Liu, S.; Nagrath, S.; Azizi, E.; Wicha, M.S. Breast Cancer Stem Cells: Current Advances and Clinical Implications. In Mammary Stem Cells: Methods and Protocols; Vivanco, M.d.M., Ed.; Methods in Molecular Biology; Springer: New York, NY, USA, 2015; Volume 1293, pp. 1-49, ISBN 978-1-4939-2518-6.

100. Liu, Z.-B.; Ezzedine, N.E.; Eterovic, A.K.; Ensor, J.E.; Huang, H.J.; Albanell, J.; Choi, D.S.; Lluch, A.; Liu, Y.; Rojo, F.; et al. Detection of breast cancer stem cell gene mutations in circulating free DNA during the evolution of metastases. Breast Cancer Res. Treat. 2019, 178, 251-261. [CrossRef]

101. Raskov, H.; Søby, J.H.; Troelsen, J.; Bojesen, R.D.; Gögenur, I. Driver Gene Mutations and Epigenetics in Colorectal Cancer. Ann. Surg. 2020, 271, 75-85. [CrossRef] [PubMed]

102. Zmrzljak, U.P.; Košir, R.; Krivokapić, Z.; Radojković, D.; Nikolić, A. Detection of Somatic Mutations with ddPCR from Liquid Biopsy of Colorectal Cancer Patients. Genes 2021, 12, 289. [CrossRef]

103. Vessies, D.C.L.; Greuter, M.J.E.; van Rooijen, K.L.; Linders, T.C.; Lanfermeijer, M.; Ramkisoensing, K.L.; Meijer, G.A.; Koopman, M.; Coupé, V.M.H.; Vink, G.R.; et al. Performance of four platforms for KRAS mutation detection in plasma cell-free DNA: ddPCR, Idylla, COBAS z480 and BEAMing. Sci. Rep. 2020, 10, 8122. [CrossRef] [PubMed]

104. Leick, K.M.; Kazarian, A.G.; Rajput, M.; Tomanek-Chalkley, A.; Miller, A.; Shrader, H.R.; McCarthy, A.; Coleman, K.L.; Kasi, P.M.; Chan, C.H.F. Peritoneal Cell-Free Tumor DNA as Biomarker for Peritoneal Surface Malignancies. Ann. Surg. Oncol. 2020, 27, 5065-5071. [CrossRef]

105. Van't Erve, I.; Rovers, K.P.; Constantinides, A.; Bolhuis, K.; Wassenaar, E.C.E.; Lurvink, R.J.; Huysentruyt, C.J.; Snaebjornsson, P.; Boerma, D.; Broek, D.; et al. Detection of tumor-derived cell-free DNA from colorectal cancer peritoneal metastases in plasma and peritoneal fluid. J. Pathol. Clin. Res. 2021, 7, 203-208. [CrossRef]

106. Crisafulli, G.; Mussolin, B.; Cassingena, A.; Montone, M.; Bartolini, A.; Barault, L.; Martinetti, A.; Morano, F.; Pietrantonio, F.; Sartore-Bianchi, A.; et al. Whole exome sequencing analysis of urine trans-renal tumour DNA in metastatic colorectal cancer patients. ESMO Open 2019, 4, e000572. [CrossRef] [PubMed]

107. Galbiati, S.; Damin, F.; Burgio, V.; Brisci, A.; Soriani, N.; Belcastro, B.; Di Resta, C.; Gianni, L.; Chiari, M.; Ronzoni, M.; et al. Evaluation of three advanced methodologies, COLD-PCR, microarray and ddPCR, for identifying the mutational status by liquid biopsies in metastatic colorectal cancer patients. Clin. Chim. Acta 2019, 489, 136-143. [CrossRef] 
108. Whale, A.S.; Devonshire, A.S.; Karlin-Neumann, G.; Regan, J.; Javier, L.; Cowen, S.; Fernandez-Gonzalez, A.; Jones, G.M.; Redshaw, N.; Beck, J.; et al. International Interlaboratory Digital PCR Study Demonstrating High Reproducibility for the Measurement of a Rare Sequence Variant. Anal. Chem. 2017, 89, 1724-1733. [CrossRef] [PubMed]

109. Junca, A.; Tachon, G.; Evrard, C.; Villalva, C.; Frouin, E.; Karayan-Tapon, L.; Tougeron, D. Detection of Colorectal Cancer and Advanced Adenoma by Liquid Biopsy (Decalib Study): The ddPCR Challenge. Cancers 2020, 12, 1482. [CrossRef]

110. Liebs, S.; Keilholz, U.; Kehler, I.; Schweiger, C.; Haybäck, J.; Nonnenmacher, A. Detection of mutations in circulating cell-free DNA in relation to disease stage in colorectal cancer. Cancer Med. 2019, 8, 3761-3769. [CrossRef] [PubMed]

111. Lueong, S.S.; Herbst, A.; Liffers, S.-T.; Bielefeld, N.; Horn, P.A.; Tannapfel, A.; Reinacher-Schick, A.; Hinke, A.; Hegewisch-Becker, S.; Kolligs, F.T.; et al. Serial Circulating Tumor DNA Mutational Status in Patients with KRAS -Mutant Metastatic Colorectal Cancer from the Phase 3 AIO KRK0207 Trial. Clin. Chem. 2020, 66, 1510-1520. [CrossRef]

112. Klein-Scory, S.; Wahner, I.; Maslova, M.; Al-Sewaidi, Y.; Pohl, M.; Mika, T.; Ladigan, S.; Schroers, R.; Baraniskin, A. Evolution of RAS Mutational Status in Liquid Biopsies During First-Line Chemotherapy for Metastatic Colorectal Cancer. Front. Oncol. 2020, 10, 1-11. [CrossRef]

113. Misale, S.; Arena, S.; Lamba, S.; Siravegna, G.; Lallo, A.; Hobor, S.; Russo, M.; Buscarino, M.; Lazzari, L.; Sartore-Bianchi, A.; et al. Blockade of EGFR and MEK Intercepts Heterogeneous Mechanisms of Acquired Resistance to Anti-EGFR Therapies in Colorectal Cancer. Sci. Transl. Med. 2014, 6, 224ra26-224ra26. [CrossRef]

114. Raimondi, C.; Nicolazzo, C.; Belardinilli, F.; Loreni, F.; Gradilone, A.; Mahdavian, Y.; Gelibter, A.; Giannini, G.; Cortesi, E.; Gazzaniga, P. Transient Disappearance of RAS Mutant Clones in Plasma: A Counterintuitive Clinical Use of EGFR Inhibitors in RAS Mutant Metastatic Colorectal Cancer. Cancers 2019, 11, 42. [CrossRef]

115. Lièvre, A.; Bachet, J.-B.; Boige, V.; Cayre, A.; Le Corre, D.; Buc, E.; Ychou, M.; Bouché, O.; Landi, B.; Louvet, C.; et al. KRAS Mutations As an Independent Prognostic Factor in Patients with Advanced Colorectal Cancer Treated with Cetuximab. J. Clin. Oncol. 2008, 26, 374-379. [CrossRef]

116. Amado, R.G.; Wolf, M.; Peeters, M.; Van Cutsem, E.; Siena, S.; Freeman, D.J.; Juan, T.; Sikorski, R.; Suggs, S.; Radinsky, R.; et al. Wild-Type KRAS Is Required for Panitumumab Efficacy in Patients with Metastatic Colorectal Cancer. J. Clin. Oncol. 2008, 26, 1626-1634. [CrossRef] [PubMed]

117. Misale, S.; Yaeger, R.; Hobor, S.; Scala, E.; Janakiraman, M.; Liska, D.; Valtorta, E.; Schiavo, R.; Buscarino, M.; Siravegna, G.; et al. Emergence of KRAS mutations and acquired resistance to anti-EGFR therapy in colorectal cancer. Nature 2012, 486, 532-536. [CrossRef] [PubMed]

118. Sanz-Garcia, E.; Argiles, G.; Elez, E.; Tabernero, J. BRAF mutant colorectal cancer: Prognosis, treatment, and new perspectives. Ann. Oncol. 2017, 28, 2648-2657. [CrossRef] [PubMed]

119. Silveira, A.B.; Bidard, F.-C.; Kasperek, A.; Melaabi, S.; Tanguy, M.-L.; Rodrigues, M.; Bataillon, G.; Cabel, L.; Buecher, B.; Pierga, J.-Y.; et al. High-Accuracy Determination of Microsatellite Instability Compatible with Liquid Biopsies. Clin. Chem. 2020, 66, 606-613. [CrossRef] [PubMed]

120. Takai, E.; Totoki, Y.; Nakamura, H.; Morizane, C.; Nara, S.; Hama, N.; Suzuki, M.; Furukawa, E.; Kato, M.; Hayashi, H.; et al. Clinical utility of circulating tumor DNA for molecular assessment in pancreatic cancer. Sci. Rep. 2015, 5, 1-10. [CrossRef]

121. Mohan, S.; Ayub, M.; Rothwell, D.G.; Gulati, S.; Kilerci, B.; Hollebecque, A.; Sun Leong, H.; Smith, N.K.; Sahoo, S.; Descamps, T.; et al. Analysis of circulating cell-free DNA identifies KRAS copy number gain and mutation as a novel prognostic marker in Pancreatic cancer. Sci. Rep. 2019, 9, 1-6. [CrossRef]

122. Ako, S.; Nouso, K.; Kinugasa, H.; Dohi, C.; Matushita, H.; Mizukawa, S.; Muro, S.; Akimoto, Y.; Uchida, D.; Tomoda, T.; et al. Utility of serum DNA as a marker for KRAS mutations in pancreatic cancer tissue. Pancreatology 2017, 17, 285-290. [CrossRef] [PubMed]

123. Sugimori, M.; Sugimori, K.; Tsuchiya, H.; Suzuki, Y.; Tsuyuki, S.; Kaneta, Y.; Hirotani, A.; Sanga, K.; Tozuka, Y.; Komiyama, S.; et al. Quantitative monitoring of circulating tumor DNA in patients with advanced pancreatic cancer undergoing chemotherapy. Cancer Sci. 2020, 111, 266-278. [CrossRef]

124. Earl, J.; Garcia-Nieto, S.; Martinez-Avila, J.C.; Montans, J.; Sanjuanbenito, A.; Rodríguez-Garrote, M.; Lisa, E.; Mendía, E.; Lobo, E.; Malats, N.; et al. Circulating tumor cells (Ctc) and kras mutant circulating free Dna (cfdna) detection in peripheral blood as biomarkers in patients diagnosed with exocrine pancreatic cancer. BMC Cancer 2015, 15, 1-10. [CrossRef] [PubMed]

125. Li, M.; Alnaggar, M.; Liang, S.; Chen, J.; Xu, K.; Dong, S.; Du, D.; Niu, L.; Yin, Z. Erratum: Circulating tumor DNA as a sensitive marker in patients undergoing irreversible electroporation for pancreatic cancer (Cellular Physiology and Biochemistry (2018) 47 (1556-1564) DOI: 10.1159/000490874). Cell. Physiol. Biochem. 2018, 48, 1397. [CrossRef]

126. Hadano, N.; Murakami, Y.; Uemura, K.; Hashimoto, Y.; Kondo, N.; Nakagawa, N.; Sueda, T.; Hiyama, E. Prognostic value of circulating tumour DNA in patients undergoing curative resection for pancreatic cancer. Br. J. Cancer 2016, 115, 59-65. [CrossRef]

127. Kim, M.K.; Woo, S.M.; Park, B.; Yoon, K.A.; Kim, Y.H.; Joo, J.; Lee, W.J.; Han, S.S.; Park, S.J.; Kong, S.Y. Prognostic implications of multiplex detection of KRAS mutations in cell-Free DNA from patients with pancreatic ductal adenocarcinoma. Clin. Chem. 2018, 64, 726-734. [CrossRef] [PubMed]

128. Watanabe, F.; Suzuki, K.; Tamaki, S.; Abe, I.; Endo, Y.; Takayama, Y.; Ishikawa, H.; Kakizawa, N.; Saito, M.; Futsuhara, K.; et al. Longitudinal monitoring of KRAS-mutated circulating tumor DNA enables the prediction of prognosis and therapeutic responses in patients with pancreatic cancer. PLoS ONE 2019, 14, e227366. [CrossRef] 
129. Allenson, K.; Castillo, J.; San Lucas, F.A.; Scelo, G.; Kim, D.U.; Bernard, V.; Davis, G.; Kumar, T.; Katz, M.; Overman, M.J.; et al. High prevalence of mutant KRAS in circulating exosome-derived DNA from early-stage pancreatic cancer patients. Ann. Oncol. 2017, 28, 741-747. [CrossRef]

130. Van Cutsem, E.; Cervantes, A.; Adam, R.; Sobrero, A.; Van Krieken, J.H.; Aderka, D.; Aranda Aguilar, E.; Bardelli, A.; Benson, A.; Bodoky, G.; et al. ESMO consensus guidelines for the management of patients with metastatic colorectal cancer. Ann. Oncol. 2016, 27, 1386-1422. [CrossRef]

131. Boysen, A.K.; Sørensen, B.S.; Lefevre, A.C.; Abrantes, R.; Johansen, J.S.; Jensen, B.V.; Schou, J.V.; Larsen, F.O.; Nielsen, D.; Taflin, H.; et al. Methodological development and biological observations of cell free DNA with a simple direct fluorescent assay in colorectal cancer. Clin. Chim. Acta 2018, 487, 107-111. [CrossRef]

132. Holm, M.; Andersson, E.; Osterlund, E.; Ovissi, A.; Soveri, L.-M.; Anttonen, A.-K.; Kytölä, S.; Aittomäki, K.; Osterlund, P.; Ristimäki, A. Detection of KRAS mutations in liquid biopsies from metastatic colorectal cancer patients using droplet digital PCR, Idylla, and next generation sequencing. PLoS ONE 2020, 15, e0239819. [CrossRef]

133. Yap, S.A.; Münster-Wandowski, A.; Nonnenmacher, A.; Keilholz, U.; Liebs, S. Analysis of cancer-related mutations in extracellular vesicles RNA by Droplet Digital ${ }^{\mathrm{TM}}$ PCR. Biotechniques 2020, 69, 99-107. [CrossRef] [PubMed]

134. Lin, A.; Zhang, J.; Luo, P. Crosstalk Between the MSI Status and Tumor Microenvironment in Colorectal Cancer. Front. Immunol. 2020, 11, 1-13. [CrossRef] [PubMed]

135. Le, D.T.; Durham, J.N.; Smith, K.N.; Wang, H.; Bartlett, B.R.; Aulakh, L.K.; Lu, S.; Kemberling, H.; Wilt, C.; Luber, B.S.; et al. Mismatch repair deficiency predicts response of solid tumors to PD-1 blockade. Science 2017, 357, 409-413. [CrossRef] [PubMed]

136. Sanabria Mateos, R.; Conlon, K.C. Pancreatic cancer. Surgery 2016, 34, 282-291. [CrossRef]

137. Pelosi, E.; Castelli, G.; Testa, U. Pancreatic Cancer: Molecular Characterization, Clonal Evolution and Cancer Stem Cells. Biomedicines 2017, 5, 65. [CrossRef]

138. Golan, T.; Hammel, P.; Reni, M.; Van Cutsem, E.; Macarulla, T.; Hall, M.J.; Park, J.-O.; Hochhauser, D.; Arnold, D.; Oh, D.-Y.; et al. Maintenance Olaparib for Germline BRCA -Mutated Metastatic Pancreatic Cancer. N. Engl. J. Med. 2019, 381, 317-327. [CrossRef]

139. Buscail, L.; Bournet, B.; Cordelier, P. Role of oncogenic KRAS in the diagnosis, prognosis and treatment of pancreatic cancer. Nat. Rev. Gastroenterol. Hepatol. 2020, 17, 153-168. [CrossRef]

140. Woo, S.M.; Kim, M.K.; Joo, J.; Yoon, K.-A.; Park, B.; Park, S.-J.; Han, S.-S.; Lee, J.H.; Hong, E.K.; Kim, Y.-H.; et al. Induction Chemotherapy with Gemcitabine and Cisplatin Followed by Simultaneous Integrated Boost-Intensity Modulated Radiotherapy with Concurrent Gemcitabine for Locally Advanced Unresectable Pancreatic Cancer: Results from a Feasibility Study. Cancer Res. Treat. 2017, 49, 1022-1032. [CrossRef]

141. Sausen, M.; Phallen, J.; Adleff, V.; Jones, S.; Leary, R.J.; Barrett, M.T.; Anagnostou, V.; Parpart-Li, S.; Murphy, D.; Li, Q.K.; et al. Clinical implications of genomic alterations in the tumour and circulation of pancreatic cancer patients. Nat. Commun. 2015, 6, 1-6. [CrossRef] [PubMed]

142. Cheng, H.; Liu, C.; Jiang, J.; Luo, G.; Lu, Y.; Jin, K.; Guo, M.; Zhang, Z.; Xu, J.; Liu, L.; et al. Analysis of ctDNA to predict prognosis and monitor treatment responses in metastatic pancreatic cancer patients. Int. J. Cancer 2017, 140, 2344-2350. [CrossRef] [PubMed]

143. ClinicalTrials.gov. Available online: https:/ / clinicaltrials.gov / (accessed on 2 July 2021).

144. Garcia, J.; Kamps-Hughes, N.; Geiguer, F.; Couraud, S.; Sarver, B.; Payen, L.; Ionescu-Zanetti, C. Sensitivity, specificity, and accuracy of a liquid biopsy approach utilizing molecular amplification pools. Sci. Rep. 2021, 11, 10761. [CrossRef] 